\title{
The Wageningen Lowland Runoff Simulator (WALRUS): a lumped rainfall-runoff model for catchments with shallow groundwater
}

\author{
C. C. Brauer, A. J. Teuling, P. J. J. F. Torfs, and R. Uijlenhoet \\ Hydrology and Quantitative Water Management Group, Wageningen University, Wageningen, the Netherlands \\ Correspondence to: C. C. Brauer (claudia.brauer@wur.nl)
}

Received: 2 January 2014 - Published in Geosci. Model Dev. Discuss.: 12 February 2014

Revised: 30 June 2014 - Accepted: 23 July 2014 - Published: 10 October 2014

\begin{abstract}
We present the Wageningen Lowland Runoff Simulator (WALRUS), a novel rainfall-runoff model to fill the gap between complex, spatially distributed models which are often used in lowland catchments and simple, parametric (conceptual) models which have mostly been developed for sloping catchments. WALRUS explicitly accounts for processes that are important in lowland areas, notably (1) groundwater-unsaturated zone coupling, (2) wetnessdependent flow routes, (3) groundwater-surface water feedbacks and (4) seepage and surface water supply. WALRUS consists of a coupled groundwater-vadose zone reservoir, a quickflow reservoir and a surface water reservoir. WALRUS is suitable for operational use because it is computationally efficient and numerically stable (achieved with a flexible time step approach). In the open source model code default relations have been implemented, leaving only four parameters which require calibration. For research purposes, these defaults can easily be changed. Numerical experiments show that the implemented feedbacks have the desired effect on the system variables.
\end{abstract}

\section{Introduction}

Lowlands, especially those in river deltas, are often densely populated and centres of agricultural production, economic activity and transportation. Therefore, socio-economic consequences of natural hazards are specially large in these areas. In addition, their low elevations and mild slopes increase their vulnerability to flooding (coastal, fluvial and pluvial), climate change, and deterioration of water quality. To mitigate natural and human disasters, hydrological models can be used by water managers as a tool for risk assessment and infrastructure design. Lowlands, defined here as areas with shallow groundwater tables, exist all over the world: $13 \%$ of the world's land surface has groundwater tables shallower than $2 \mathrm{~m}$ and $22 \%$ shallower than $4 \mathrm{~m}$ (Fig. 1; data from Fan et al., 2013). This indicates that being able to understand and model lowland-specific hydrologic processes is beneficial for scientists and practitioners around the world.

Many types of hydrological models exist and they vary widely in their degree of complexity. The appropriate degree of complexity depends on the objectives of the model study and the catchment the model is applied to (Wagener et al., 2001). Here, we focus on models to simulate catchment runoff, or, more accurately, the changes in river discharge resulting from hydrological processes within the catchment (the terms runoff and discharge are used interchangeably in this paper). Between detailed, spatially distributed models and black box models lies the class of parametric rainfall-runoff models, which simplify hydrological systems into a collection of reservoirs and flow routes, capturing the essence of the hydrological processes, while restricting the number of parameters (Wagener and Wheater, 2004). Widely used examples of parametric rainfall-runoff models are the Tank model (Sugawara et al., 1974), PDM (Moore, 1985), HBV (Bergström and Forsman, 1973), the Sacramento model (Burnash, 1995), ARNO (Todini, 1996), SWAT (Arnold et al., 1998) and GR4J (Edijatno et al., 1999; Perrin et al., 2003). However, these models have all been developed for sloping catchments and errors may arise when applied to lowland catchments, because essential processes (e.g. capillary rise) are not accounted for and typical conditions (e.g. influence of surface water on groundwater) are not met. Examples of the resulting problems are presented by Bormann and Elfert (2010), who used WaSiM-ETH (Schulla and Jasper, 2007) and Koch et al. (2013), who used SWAT, both in northeastern Germany. 

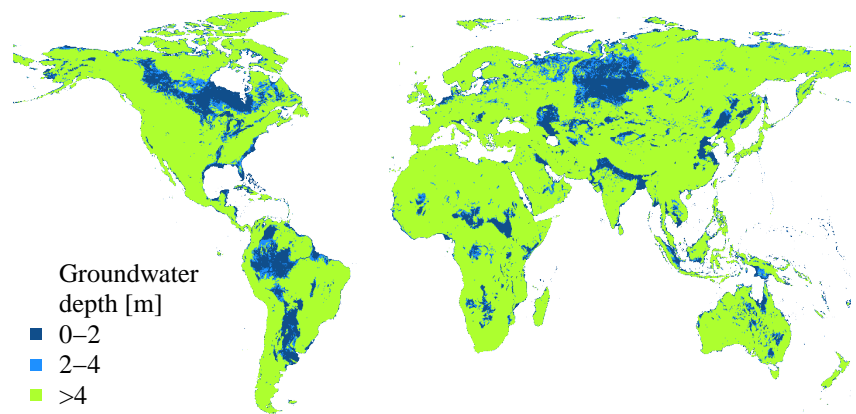

Figure 1. Locations with shallow groundwater (based on data from Fan et al., 2013). Lowland areas can be found all over the world and often in densely populated areas, which shows the relevance of WALRUS for application outside the Netherlands.

For realistic simulations of runoff, the model structure should represent the main catchment processes and therefore several models have been developed for specific catchment and climate types: (Dynamic) TOPMODEL (Beven and Kirkby, 1979; Beven and Freer, 2001) for sloping catchments, VIC (Liang et al., 1996) for areas prone to saturation excess overland flow and LGSI (Van der Velde et al., 2009) for data-rich lowland catchments. In addition, flexible model frameworks, e.g. (SUPER)FLEX (Fenicia et al., 2006, 2011) and FUSE (Clark et al., 2008), have been developed to allow for adaptation of the model structure to individual catchments.

A parametric rainfall-runoff model for lowland catchments, the Wageningen model, was developed at the Hydrology and Quantitative Water Management Group of Wageningen University in the 1970s (Stricker and Warmerdam, 1982). This parametric model accounts for certain lowlandspecific processes: capillary rise and a dynamic division between fast and slow flow routes as a function of catchment wetness. However, other lowland-specific processes are not included in the Wageningen model: the saturated and unsaturated zone are disconnected and no feedbacks are possible between groundwater and surface water. Although the Wageningen model has been widely applied in many catchments inside and outside the Netherlands, users have indicated a number of serious shortcomings, both of numeric and conceptual nature.

In response to this demand, we have developed the Wageningen Lowland Runoff Simulator (WALRUS). We aimed for an entirely new model to simulate runoff in lowland catchments, which can be used both for multi-year water balance studies and for single rainfall-runoff events. The model was designed to have an understandable model structure that incorporates the most important processes and feedbacks, with fewer than six parameters of which the values do not change with the temporal resolution at which the model is run.
In this paper we present WALRUS. First, we describe the threefold motivation for model development: general challenges in rainfall-runoff modelling (Sect. 2), the two contrasting lowland field sites which were used in the model development (Sect. 3), and challenges in modelling rainfallrunoff processes in lowland catchments (Sect. 4). In Sect. 5 we explain the model structure in detail. Section 6 contains the implementation of the model (computer code) and Sect. 7 the conclusions. A detailed model evaluation is discussed in a companion paper (Brauer et al., 2014).

\section{Challenges in rainfall-runoff modelling}

Water managers in lowland areas often use complex hydrological models. MIKE-SHE (Refsgaard and Storm, 1995), HEC-RAS (Brunner, 1995) and SOBEK (Deltares, 2013) have detailed schematisations of surface water networks to simulate the complex flow routing in intensively drained areas. HYDRUS (Šimůnek et al., 2008) and SWAP (Van Dam et al., 2008) have detailed vertical schematisations to simulate unsaturated-saturated zone coupling. Regional groundwater models, such as MODFLOW (McDonald and Harbaugh, 1984), account for seepage and lateral groundwater flow. Combinations of several of these models can be used to account for groundwater-surface water feedbacks, such as SHE (Abbott et al., 1986), HydroGeoSphere (Therrien et al., 2006) SIMGRO (Querner, 1988; Van Walsum and Veldhuizen, 2011) or NHI (Prinsen and Becker, 2011).

However, complex models have important disadvantages and simple models important advantages, particularly considering four aspects. The first aspect concerns overparameterisation. Model parameters account for differences in response times or recession shapes between catchments with the same dominant processes (represented by the model structure). With too many parameters, an inappropriate model structure can be compensated for by mathematically fitting the model to the calibration data (Kirchner, 2006). An overparameterised model may perform well during calibration, but unsatisfactorily during validation (Perrin et al., 2001) and in different (future) climate regimes (e.g. Seibert, 1999).

The second aspect concerns parameter identification. The risk of parameter dependence and equifinality (where different combinations of parameter values lead to similar results, Beven and Binley, 1992; Uhlenbrook et al., 1999) increases with the number of parameters. With one objective function, only typically three to five parameters can be identified (Jakeman and Hornberger, 1993; Beven, 1989). Multi-objective calibration allows more parameters to be calibrated (e.g. Gupta et al., 1998; Efstratiadis and Koutsoyiannis, 2010), but for many catchments only discharge data are available (Soulsby et al., 2008). It is therefore beneficial to be able to identify the effect of each parameter on the modelled discharge time series. 
The third aspect concerns physical representation. A simple, parametric model structure enables users to quickly grasp the processes covered by each model element and the influence of each parameter. Values of effective model parameters cannot be determined with point measurements (Wagener, 2003; Vrugt et al., 2005), but model parameters do have physical connotations and can be explained qualitatively from catchment characteristics and field experience (Seibert and McDonnell, 2002). The effect of small-scale heterogeneity on catchment-scale processes is included implicitly in the model parameters (Beven, 1995; Kirchner, 2006; McDonnell et al., 2007).

The final aspect concerns practical applicability. Computational efficiency facilitates operational forecasting and data assimilation (Liu et al., 2012; Rakovec et al., 2012). Ensembles can be generated for different forcing data or parameter sets to indicate predictive uncertainty (Krzysztofowicz, 2001). In addition, more complex and time-consuming algorithms can be used for calibration (e.g. DREAM by Vrugt et al., 2008) or parameter uncertainty estimation (e.g. GLUE by Beven and Binley, 1992). Avoiding the need to construct a model with channel cross sections and soil layers for each catchment can also be advantageous. These four aspects motivated us to develop a parsimonious model and apply Occam's razor where possible.

\section{Experience from two contrasting lowland catchments}

Field experience and data from two contrasting field sites in the Netherlands have been used to develop the model structure. The Hupsel Brook catchment in the east has slightly sloping surfaces and drainage is driven by gravity (freely draining). The Cabauw polder in the west is flat and its water levels are controlled with weirs and supply of surface water. The Hupsel Brook catchment is $6.5 \mathrm{~km}^{2}$, its soils consist of $0.2-11 \mathrm{~m}$ of loamy sand on an impermeable clay layer and land cover is mostly grass $(59 \%)$ and some maize $(33 \%)$. The Cabauw polder is $0.5 \mathrm{~km}^{2}$, its soils consist of about $70 \mathrm{~cm}$ heavy clay on peat and land cover is $80 \%$ grass, $15 \%$ maize and $5 \%$ surface water. A more detailed description of both catchments and observations is presented in an accompanying paper (Brauer et al., 2014).

From the Hupsel Brook catchment, we used combined observations of groundwater and soil moisture (from a neutron probe at 12 depths, ranging from 0.15 to $2.05 \mathrm{~m}$; period 1976-1984) at six locations, which represent the spatial variability in the catchment well. Potential evapotranspiration was estimated with the method of Thom and Oliver (1977). During the growing seasons (15 April-14 September) of 1976 through 1982 daily sums of actual evapotranspiration $\left(\mathrm{ET}_{\mathrm{act}}\right)$ have been computed with the energy budget method: net radiation was measured and wind and temperature profile measurements were used to estimate sensible and ground heat flux. Evapotranspiration was then estimated as residual of the energy budget (for more information see Stricker and Brutsaert, 1978). In addition, we used data from 1993: discharge measured with a type of H-flume, groundwater depths measured at the meteorological station and total phosphorus, nitrate and chloride concentrations measured at the catchment outlet.

From the Cabauw polder, we used daily soil moisture data from four arrays of six TDR sensors between 5 and $73 \mathrm{~cm}$ deep from the period 2003-2010. Groundwater depth was measured at the same location. Potential evapotranspiration

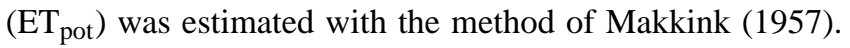
Actual evapotranspiration $\left(\mathrm{ET}_{\mathrm{act}}\right)$ was determined with an energy balance method (Beljaars and Bosveld, 1997). Net radiation and ground heat flux were measured and the Bowen ratio was determined with eddy covariance measurements. Evapotranspiration was obtained by dividing the available energy (net radiation minus ground heat flux) between latent and sensible heat fluxes according to the Bowen ratio. Because $\mathrm{ET}_{\mathrm{act}}$ estimated with this method was on average $4 \%$ higher than $\mathrm{ET}_{\text {pot }}$ during well-watered conditions, we divided $\mathrm{ET}_{\text {act }}$ by 1.04 .

\section{Challenges in modelling rainfall-runoff processes in lowland catchments}

In this section we discuss some characteristics which affect hydrological processes in lowland catchments. We discuss how they are represented in some widely used rainfall-runoff models and how they are accounted for explicitly in WALRUS.

\subsection{Groundwater-unsaturated zone coupling}

Whereas in most models percolation is assumed to be driven by downward gravitational forces only, the vertical profile of moisture content in lowland soils is influenced by capillary forces associated with the presence of a shallow groundwater table. Percolation is slower and evapotranspiration remains high in dry periods, because storage deficits are replenished by capillary rise (e.g. Hopmans and van Immerzeel, 1988; Stenitzer et al., 2007). Therefore, the vadose zone and the groundwater zone form a tightly coupled system and feedbacks should be included in models for lowland catchments (Chen and $\mathrm{Hu}, 2004)$. In addition, when groundwater rises to the soil surface, the unsaturated zone shrinks and its storage capacity decreases. It is therefore important to include a dynamic unsaturated zone in the model, which is influenced by the surface fluxes precipitation and evapotranspiration as well as by the (dynamic) groundwater table below.

Many conceptual rainfall-runoff models, e.g. HBV and the Sacramento model contain separate reservoirs for soil moisture and groundwater, allowing only downward movement of groundwater without considering feedbacks. One version of PDM does reduce recharge when the soil 


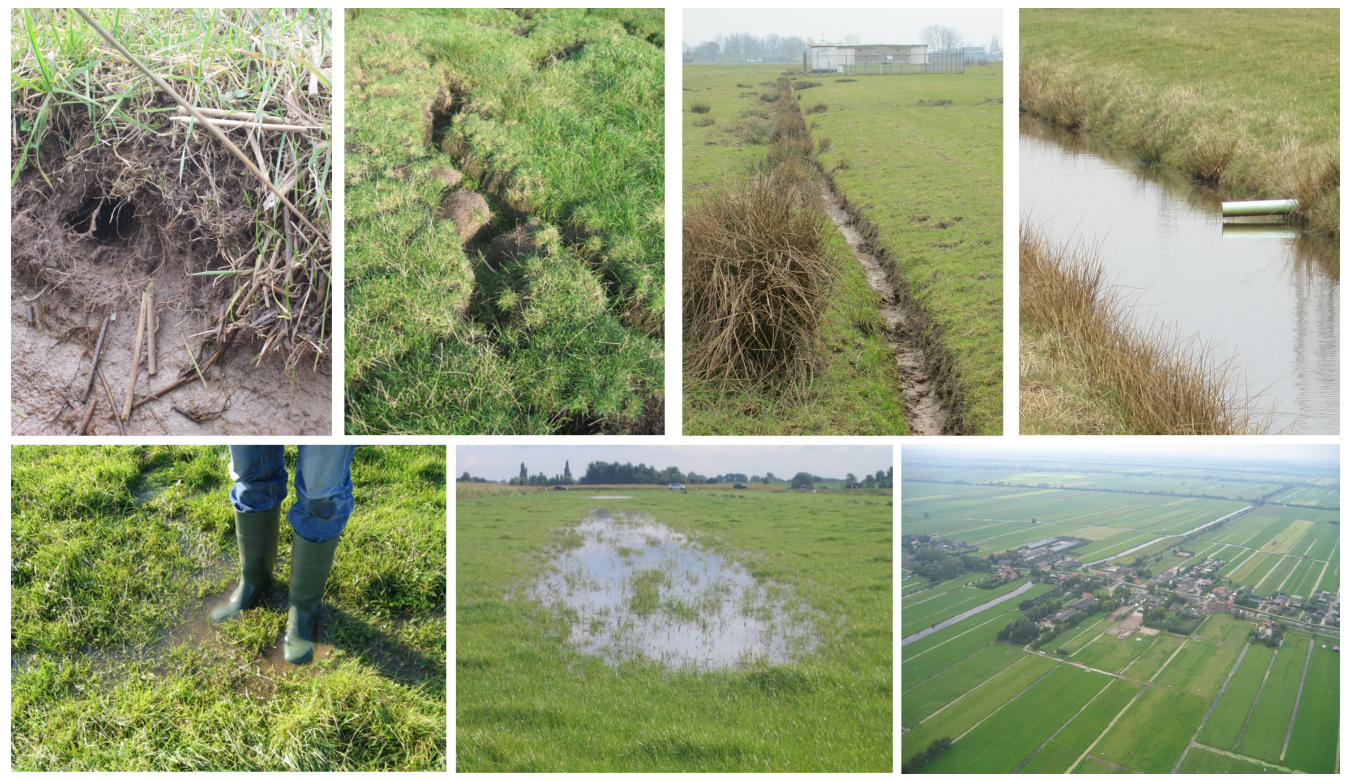

Figure 2. Discharge mechanisms at different scales in the Cabauw polder. Top row: animal burrow, soil cracks, gully, drainpipe. Bottom row: local ponding, field-scale ponding, surface water network.

ceases to be freely draining (Moore, 2007). Catchments can also be simplified to a single nonlinear reservoir, without discriminating between the saturated and unsaturated zone (Kirchner, 2009), which yielded limited success in the lowland Hupsel Brook catchment (Brauer et al., 2013). Quasisteady-state approaches have also been developed for implementation in distributed models, e.g. by Koster et al. (2000), Bogaart et al. (2008) and Van Walsum and Groenendijk (2008). A parsimonious rainfall-runoff model for lowland catchments requires a single soil reservoir, which includes both the unsaturated and the saturated zone.

\subsection{Shallow groundwater and plant water stress}

Vegetation in lowland catchments is hardly affected by water stress, which is one of the drivers for high agricultural production. Water is not only made available through physical processes (capillary rise), but also through physiological ones: when plants have exhausted the readily available moisture in the top soil, deeper roots are used (Zencich et al., 2002), and vertical roots grow deeper (Canadell et al., 1996; Weir and Barraclough, 1986; Teuling et al., 2006) and more quickly (Zeng et al., 2013). Because plants adapt to spatial variability in moisture content, water uptake and its vertical distribution depend primarily on the availability of moisture in the whole root zone (Jarvis, 1989). As roots in lowlands often extend to close to the groundwater table, plants can adapt fully to dry periods and evapotranspiration reduction hardly occurs (Schenk and Jackson, 2002). This dynamic system of different plant species with varying stages of root development and spatially and temporally varying groundwater depths is complex, but it may not be necessary to include all complexity in a model for runoff simulations (Van der Ploeg et al., 2012). In addition, the entire system of feedbacks between plants and water is complex on small scales, but likely less complex on larger scales.

In some rainfall-runoff models for areas with groundwater tables, a separate root zone is included, e.g. in SWAT and TOPMODEL, which exhibits a different behaviour than the unsaturated zone below. We assume that in lowlands, this distinction cannot be made because the whole unsaturated zone can be used by plant roots. The variation of plant species within a catchment is sometimes represented by running a model for different vegetation types separately and multiplying the resulting discharge output with the fraction of that vegetation type (Van Dam et al., 2008). To reduce the risk of overparameterisation, spatial variation in vegetation and root water uptake does not need to be modelled explicitly in a model for discharge simulations.

\subsection{Wetness-dependent flow routes}

When the soil wetness increases, different flow paths are activated: from groundwater flow (Hall, 1968), to natural macropores (Mosley, 1979; Beven and Germann, 1982, 2013; McDonnell, 2003) and drainpipes (Tiemeyer et al., 2007; Rozemeijer et al., 2010a; Van der Velde et al., 2010b) and eventually to surface runoff (Dunne and Black, 1970; Brauer et al., 2011; Appels et al., 2011). Figure 2 provides examples of discharge mechanisms in lowland catchments at different scales.

Stream water chemistry is increasingly being used to detect hydrological flow paths (e.g. Soulsby et al., 2004; Tetzlaff et al., 2007; Delsman et al., 2013). Records of phosphorus, nitrate and chloride concentrations measured at the 

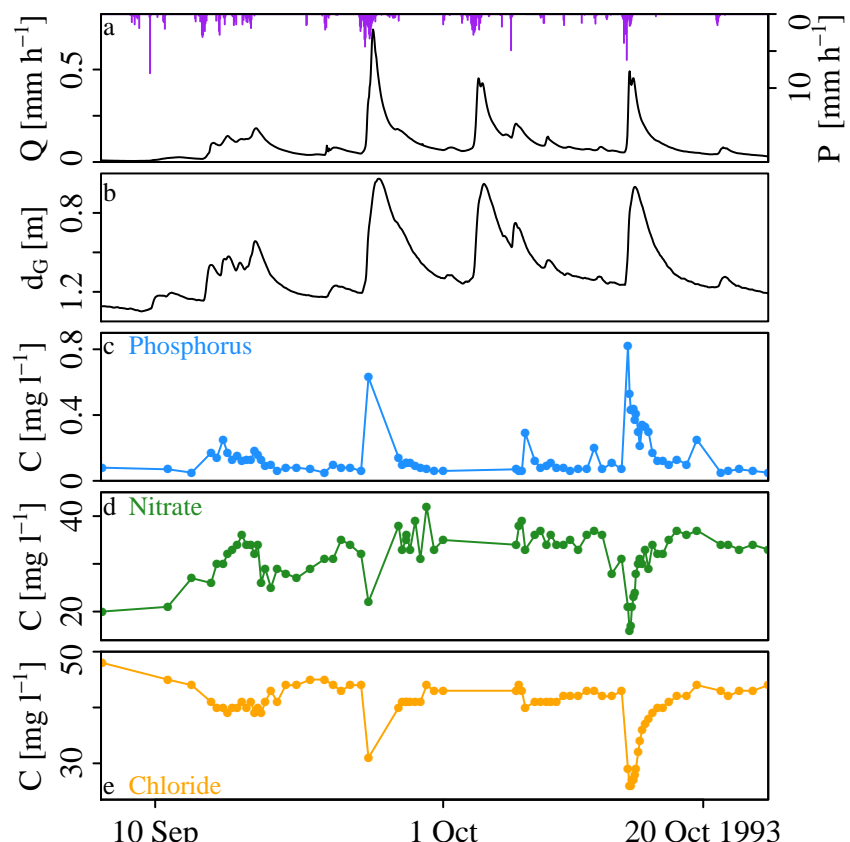

$10 \mathrm{Sep}$

1 Oct

20 Oct 1993

Figure 3. Activation of different flow paths revealed by water quality data measured at the outlet of the Hupsel Brook catchment. (a) Precipitation and discharge. (b) Groundwater depth at the meteorological station. (c) Phosphorus concentration (indicator for overland flow, Rozemeijer et al., 2010b), (d) Nitrate concentration (indicator for drainpipe flow, Van der Velde et al., 2010b). (e) Chloride concentration (indicator for groundwater flow, Van der Velde et al., 2010a).

outlet of the Dutch Hupsel Brook catchment confirm the activation of different flow routes at different stages of catchment wetness (Fig. 3). The activation of drainpipes in September is indicated by increasing nitrate concentrations and overland flow during peaks by decreasing chloride and nitrate concentrations and increasing phosphorus concentrations.

The contribution of preferential flow and macropore flow can be considerable and needs to be accounted for in the model structure (Beven and Germann, 1982; Weiler and McDonnell, 2004; Hansen et al., 2013). Drainpipes can be viewed as man-made macropores (Herrmann and Duncker, 2008) and account for a large fraction (up to $80 \%$ ) of drainage in lowlands (Van der Velde et al., 2011; Turunen et al., 2013). When local storage thresholds are exceeded and quickflow paths are activated, a sudden increase in local discharge occurs (the fill and spill hypothesis by Trompvan Meerveld and McDonnell, 2006), but at the catchment scale, sudden changes in discharge are hardly ever observed, because spatial variability in groundwater depth, drainpipe depth and microtopography cause these thresholds to be reached at different moments at different locations (Appels, 2013).
Parametric models often divide water between fast and slow routes. In the GR4J model (Perrin et al., 2003) this division is fixed, the PDM model (Moore, 1985) uses a wetnessdependent probability distribution to express the spatial variability in quickflow contribution, and in the Wageningen model (Stricker and Warmerdam, 1982) the division depends on groundwater storage. A division between slow and fast flow routes, which depends on catchment wetness in a parsimonious way, is indispensable for adequate runoff simulations in lowland catchments.

\subsection{Groundwater-surface water feedbacks}

Surface water is an important feature in lowland landscapes (Fig. 2). The aim of man-made drainage networks in controlled catchments is to optimise groundwater depths by adjusting surface water levels (Krause et al., 2007). During discharge peaks, backwater feedbacks can occur and high surface water levels reduce groundwater drainage or may even cause infiltration (Brauer et al., 2011).

Most parametric rainfall-runoff models do not simulate surface water levels, and therefore parametric models for vertical flow in the unsaturated zone are often coupled to a distributed groundwater model for studies on groundwater-surface water interactions (Krause and Bronstert, 2007; Sophocleous and Perkins, 2000; Lasserre et al., 1999; Van der Velde et al., 2009). In a rainfall-runoff model for lowland catchments, surface water should form an integral part of the model structure to account for groundwatersurface water feedbacks.

\subsection{Seepage and surface water supply}

Regional groundwater flow is common in lowland areas and upward or downward seepage can be a large term in the water budget. Surface water is often supplied to raise groundwater levels for optimal crop growth, to avoid algal blooms (by maintaining flow velocity), to reduce brackish seepage in coastal areas below sea level, or to prevent peat oxidation. In addition, the water can be removed from the catchment by pumping (Van den Eertwegh et al., 2006; Te Brake et al., 2013; Delsman et al., 2013).

Usually, distributed models are used for regional groundwater flow (MODFLOW), surface water supply and extraction (MIKE-SHE, SOBEK) and control operations (Van Andel et al., 2010) and the effect of changing surface water levels on runoff generation is not taken into account. A rainfallrunoff model for lowland catchments should include options for seepage and surface water supply and extraction.

\section{Model description}

In this section we provide a detailed description of all model components: reservoirs, states, fluxes and feedback mechanisms. The model contains several relations between model 
Table 1. Overview of variables, parameters and functions. All fluxes are catchment averages, both external ones (including $Q$ and $f_{\mathrm{XS}}$ ) and internal fluxes (which are multiplied with the relative surface area of the reservoir in question). Note that $d_{\mathrm{V}}, h_{\mathrm{Q}}$ and $h_{\mathrm{S}}$ result from the mass balances in the three reservoirs, while $d_{\mathrm{G}}$ is only used as pressure head to compute the groundwater drainage flux. The names of the fluxes are derived from the reservoirs (for example $f_{\mathrm{XS}}$ : $f$ stands for flow, the $\mathrm{X}$ for external and the $\mathrm{S}$ for surface water - water flowing from outside the catchment into the surface water network).

\begin{tabular}{|c|c|c|c|}
\hline & States & & \\
\hline$d \mathrm{~V}$ & storage deficit & $\rightarrow \frac{\mathrm{d} d d_{\mathrm{V}}}{\mathrm{d} t}=-\frac{f_{\mathrm{XG}}+P_{\mathrm{V}}-\mathrm{ET}_{\mathrm{V}}-f_{\mathrm{GS}}}{a_{\mathrm{G}}}$ & $(\mathrm{mm})$ \\
\hline$d_{\mathrm{G}}$ & groundwater depth & $\rightarrow \frac{\mathrm{d} d_{\mathrm{G}}}{\mathrm{d} t}=\frac{d_{\mathrm{V}}-d_{\mathrm{V}, \mathrm{eq}}}{c_{\mathrm{V}}}$ & $(\mathrm{mm})$ \\
\hline$h_{\mathrm{Q}}$ & level quickflow reservoir & $\rightarrow \frac{\mathrm{d} h_{\mathrm{Q}}}{\mathrm{d} t}=\frac{P_{\mathrm{Q}}-f_{\mathrm{QS}}}{a_{\mathrm{G}}}$ & $(\mathrm{mm})$ \\
\hline \multirow[t]{2}{*}{$h_{\mathrm{S}}$} & surface water level & $\rightarrow \frac{\mathrm{d} h_{\mathrm{S}}}{\mathrm{d} t}=\frac{f_{\mathrm{XS}}+P_{\mathrm{S}}-\mathrm{ET} \mathrm{T}_{\mathrm{S}}+f_{\mathrm{GS}}+f_{\mathrm{QS}}-Q}{a_{\mathrm{S}}}$ & $(\mathrm{mm})$ \\
\hline & Dependent variables & & \\
\hline W & wetness index & $=\operatorname{func}\left(d_{\mathrm{V}}\right)$ & $(-)$ \\
\hline$\beta$ & evapotranspiration reduction factor & $=\operatorname{func}\left(d_{\mathrm{V}}\right)$ & $(-)$ \\
\hline \multirow[t]{2}{*}{$d_{\mathrm{V}, \mathrm{eq}}$} & equilibrium storage deficit & $=\operatorname{func}\left(d_{\mathrm{G}}\right)$ & $(\mathrm{mm})$ \\
\hline & External fluxes: input & & \\
\hline$P$ & precipitation & & $\left(\mathrm{mm} \mathrm{h}^{-1}\right)$ \\
\hline $\mathrm{ET}_{\text {pot }}$ & potential evapotranspiration & & $\left(\mathrm{mm} \mathrm{h}^{-1}\right)$ \\
\hline$Q_{\mathrm{obs}}$ & discharge (for calibration and $Q_{0}$ ) & & $\left(\mathrm{mm} \mathrm{h}^{-1}\right)$ \\
\hline$f_{\mathrm{XG}}$ & seepage (up/down)/extraction & & $\left(\mathrm{mmh}^{-1}\right)$ \\
\hline \multirow[t]{2}{*}{$f_{\mathrm{XS}}$} & surface water supply/extraction & & $\left(\mathrm{mm} \mathrm{h}^{-1}\right)$ \\
\hline & External fluxes: output & & \\
\hline $\mathrm{ET}_{\mathrm{act}}$ & actual evapotranspiration & $=\mathrm{ET}_{\mathrm{V}}+\mathrm{ET}_{\mathrm{S}}$ & $\left(\mathrm{mm} \mathrm{h}^{-1}\right)$ \\
\hline \multirow[t]{2}{*}{$Q$} & discharge & $=\operatorname{func}\left(h_{\mathrm{S}}\right)$ & $\left(\mathrm{mm} \mathrm{h}^{-1}\right)$ \\
\hline & Internal fluxes & & \\
\hline$P_{\mathrm{S}}$ & precipitation into surface water reservoir & $=P \cdot a_{\mathrm{S}}$ & $\left(\mathrm{mm} \mathrm{h}^{-1}\right)$ \\
\hline$P_{\mathrm{V}}$ & precipitation into vadose zone & $=P \cdot(1-W) \cdot a_{\mathrm{G}}$ & $\left(\mathrm{mm} \mathrm{h}^{-1}\right)$ \\
\hline$P_{\mathrm{Q}}$ & precipitation into quickflow reservoir & $=P \cdot W \cdot a_{\mathrm{G}}$ & $\left(\mathrm{mm} \mathrm{h}^{-1}\right)$ \\
\hline $\mathrm{ET}_{\mathrm{V}}$ & actual evapotranspiration vadose zone & $=\mathrm{ET}_{\mathrm{pot}} \cdot \beta \cdot a_{\mathrm{G}}$ & $\left(\mathrm{mm} \mathrm{h}^{-1}\right)$ \\
\hline $\mathrm{ET}_{\mathrm{S}}$ & actual evapotranspiration surface water & $=\mathrm{ET}_{\text {pot }} \cdot a_{\mathrm{S}}$ & $\left(\mathrm{mm} \mathrm{h}^{-1}\right)$ \\
\hline$f_{\mathrm{GS}}$ & groundwater drainage/surface water infiltration & $=\frac{\left(c_{\mathrm{D}}-d_{\mathrm{G}}-h_{\mathrm{S}}\right) \cdot \max \left(\left(c_{\mathrm{D}}-d_{\mathrm{G}}\right), h_{\mathrm{S}}\right)}{c_{\mathrm{G}}} \cdot a_{\mathrm{G}}$ & $\left(\mathrm{mm} \mathrm{h}^{-1}\right)$ \\
\hline \multirow[t]{2}{*}{$f_{\mathrm{QS}}$} & quickflow & $=\frac{h_{\mathrm{Q}}}{c_{\mathrm{Q}}} \cdot a_{\mathrm{G}}$ & $\left(\mathrm{mm} \mathrm{h}^{-1}\right)$ \\
\hline & Model parameters & & \\
\hline$c_{\mathrm{W}}$ & wetness index parameter & & $(\mathrm{mm})$ \\
\hline$c_{\mathrm{V}}$ & vadose zone relaxation time & & \\
\hline$c_{\mathrm{G}}$ & groundwater reservoir constant & & $(\mathrm{mmh})$ \\
\hline \multirow[t]{2}{*}{$c_{\mathrm{Q}}$} & quickflow reservoir constant & & (h) \\
\hline & Supplied parameters & & \\
\hline$a_{\mathrm{S}}$ & surface water area fraction & & $(-)$ \\
\hline$a_{\mathrm{G}}$ & groundwater reservoir area fraction & $=1-a_{\mathrm{S}}$ & $(-)$ \\
\hline \multirow[t]{2}{*}{$c_{\mathrm{D}}$} & channel depth & & $(\mathrm{mm})$ \\
\hline & User-defined functions with defaults & & \\
\hline$W\left(d_{\mathrm{V}}\right)$ & wetness index & $=\cos \left(\frac{\max \left(\min \left(d_{\mathrm{V}}, c_{\mathrm{W}}\right), 0\right) \cdot \pi}{c_{\mathrm{W}}}\right) \cdot \frac{1}{2}+\frac{1}{2}$ & $(-)$ \\
\hline$\beta\left(d_{\mathrm{V}}\right)$ & evapotranspiration reduction factor & $=\frac{1-\exp \left[\zeta_{1}\left(d_{\mathrm{V}}-\zeta_{2}\right)\right]}{1+\exp \left[\zeta_{1}\left(d_{\mathrm{V}}-\zeta_{2}\right)\right]} \cdot \frac{1}{2}+\frac{1}{2}$ & $(-)$ \\
\hline$d_{\mathrm{V}, \mathrm{eq}}\left(d_{\mathrm{G}}\right)$ & equilibrium storage deficit & $=\theta_{\mathrm{s}}\left(d_{\mathrm{G}}-\frac{d_{\mathrm{G}}^{1-1 / b}}{\left(1-\frac{1}{b}\right) \psi_{\mathrm{ae}}^{-1 / b}}-\frac{\psi_{\mathrm{ae}}}{1-b}\right)$ & $(\mathrm{mm})$ \\
\hline \multirow[t]{2}{*}{$Q\left(h_{\mathrm{S}}\right)$} & stage-discharge relation & $=c_{\mathrm{S}}\left(\frac{h_{\mathrm{S}}-h_{\mathrm{S}, \min }}{c_{\mathrm{D}}-h_{\mathrm{S}, \min }}\right)^{x_{\mathrm{S}}}$ & $\left(\mathrm{mm} \mathrm{h}^{-1}\right)$ \\
\hline & Parameters for default functions & & \\
\hline$\zeta_{1}$ & curvature ET reduction function & & $(-)$ \\
\hline$\zeta_{2}$ & translation ET reduction function & & $(\mathrm{mm})$ \\
\hline$b$ & pore size distribution parameter & & $(-)$ \\
\hline$\psi_{\mathrm{ae}}$ & air entry pressure & & $(\mathrm{mm})$ \\
\hline$\theta_{\mathrm{s}}$ & soil moisture content at saturation & & $(-)$ \\
\hline$c_{\mathrm{S}}$ & surface water parameter: bankfull $Q$ & & $\left(\mathrm{~mm} \mathrm{~h}^{-1}\right)$ \\
\hline & stage-discharge relation exponent & & $(-)$ \\
\hline$h_{\mathrm{S}, \min }$ & surface water level when $Q=0$ & & $(\mathrm{~mm})$ \\
\hline
\end{tabular}




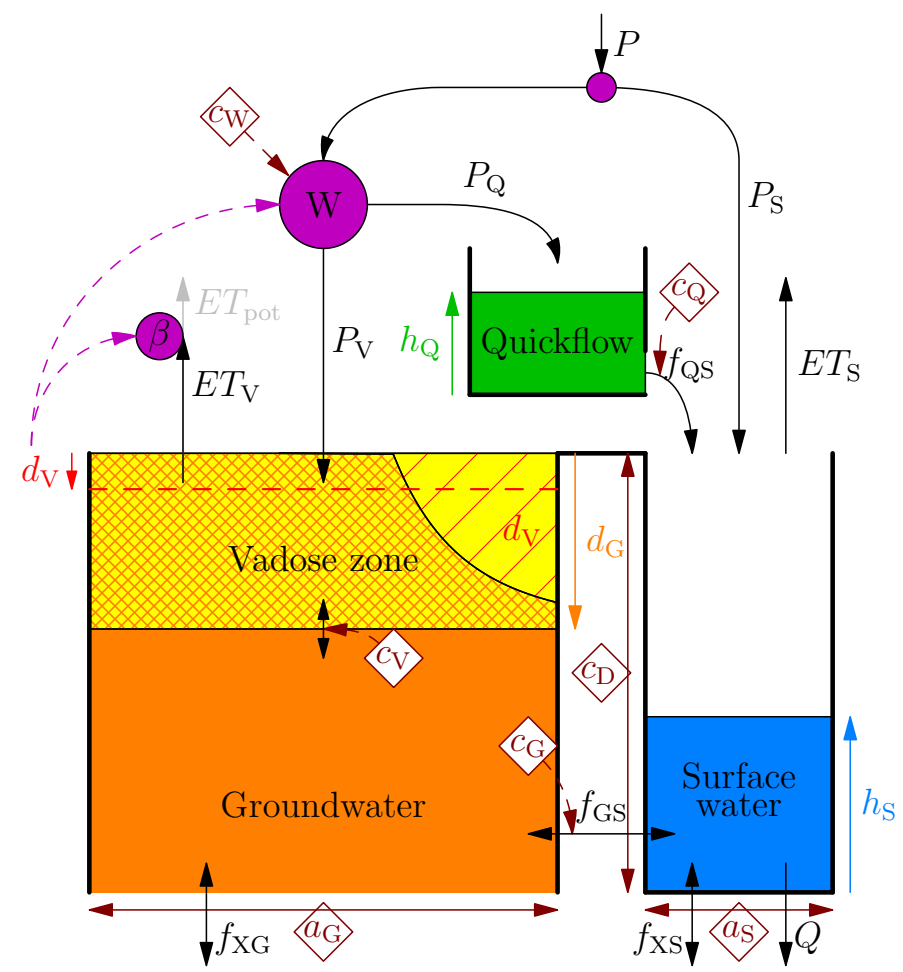

Figure 4. Overview of the model structure with the five compartments: land surface (purple), vadose zone within the soil reservoir (yellow/red hatched), groundwater zone within the soil reservoir (orange), quickflow reservoir (green) and surface water reservoir (blue). Fluxes are black arrows, model parameters brown diamonds and states in the colour of the reservoir they belong to. For a complete description of all variables, see Table 1 and Sect. 5.1. The names of the fluxes are derived from the reservoirs (for example $f_{\mathrm{XS}}: f$ stands for flow, the $\mathrm{X}$ for external and the $\mathrm{S}$ for surface water - water flowing from outside the catchment into the surface water network).

variables which can be specified by the user. We implemented defaults for these relations, such that WALRUS can be used directly by practitioners, while retaining the option to change them for research purposes.

\subsection{General overview}

WALRUS is a water balance model with three reservoirs and fluxes between the reservoirs. The model can be split into five compartments (Fig. 4, for abbreviations of variables, see Table 1):

1. Land surface - at the land surface, water is added to the different reservoirs by precipitation $(P)$. A fixed fraction is led to the surface water reservoir $\left(P_{\mathrm{S}}\right)$. The soil wetness index $(W)$ determines which fraction of the remaining precipitation percolates slowly through the soil matrix $\left(P_{\mathrm{V}}\right)$ and which fraction flows towards the surface water via quickflow routes $\left(P_{\mathrm{Q}}\right)$. Water is removed by evapotranspiration from the vadose zone $\left(\mathrm{ET}_{\mathrm{V}}\right)$ and surface water reservoir $\left(\mathrm{ET}_{\mathrm{S}}\right)$.

2. Vadose zone within the soil reservoir - the vadose zone is the upper part of the soil reservoir and extends from the soil surface to the dynamic groundwater table $\left(d_{\mathrm{G}}\right)$, including the capillary fringe. The dryness of the vadose zone is characterised by a single state: the storage deficit $\left(d_{\mathrm{V}}\right)$, which represents the effective volume of empty pores per unit area. It controls the evapotranspiration reduction $(\beta)$ and the wetness index $(W)$.

3. Groundwater zone within the soil reservoir - the phreatic groundwater extends from the groundwater depth $\left(d_{\mathrm{G}}\right)$ downwards, thereby assuming that there is no shallow impermeable soil layer and allowing groundwater to drop below the depth of the drainage channels $\left(c_{\mathrm{D}}\right)$ in dry periods. The groundwater table responds to changes in the unsaturated zone storage and determines, together with the surface water level, groundwater drainage or infiltration of surface water $\left(f_{\mathrm{GS}}\right)$.

4. Quickflow reservoir - all water that does not flow through the soil matrix, passes through the quickflow reservoir to the surface water $\left(f_{\mathrm{QS}}\right)$. This represents macropore flow through drainpipes, animal burrows and soil cracks, but also local ponding and overland flow.

5. Surface water reservoir - the surface water reservoir has a lower boundary (the channel bottom $c_{\mathrm{D}}$ ), but no upper boundary. Discharge $(Q)$ is computed from the surface water level $\left(h_{\mathrm{S}}\right)$.

6. External fluxes - water can be added to or removed from the soil reservoir by seepage $\left(f_{\mathrm{XG}}\right)$ and to/from the surface water reservoir by surface water supply or extraction $\left(f_{\mathrm{XS}}\right)$.

The area of the surface water reservoir $a_{\mathrm{S}}$ is the fraction of the catchment covered by ditches and channels, which is supplied by the user and can generally be derived from maps. The area of the soil reservoir $a_{\mathrm{G}}$ is the remainder $\left(1-a_{\mathrm{S}}\right)$. The area of the quickflow reservoir is taken equal to $a_{\mathrm{G}}$, but this is arbitrary since the outflow depends on the volume of water in the reservoir and a parameter (see Sect. 5.8). In the following sections the processes occurring within and between each compartment are discussed.

Because the soil reservoir has no lower boundary and the surface water reservoir no upper boundary, the groundwater depth $d_{\mathrm{G}}$ is measured with respect to the soil surface and the surface water level $h_{\mathrm{S}}$ with respect to the channel bottom. The channel bottom $c_{\mathrm{D}}$, with respect to the soil surface, is used to compute the difference in level, which is necessary for the computation of groundwater drainage. The quickflow reservoir level $h_{\mathrm{Q}}$ is measured with respect to the bottom of that reservoir. The storage deficit $d_{\mathrm{V}}$ is an effective thickness, instead of a level or depth. 


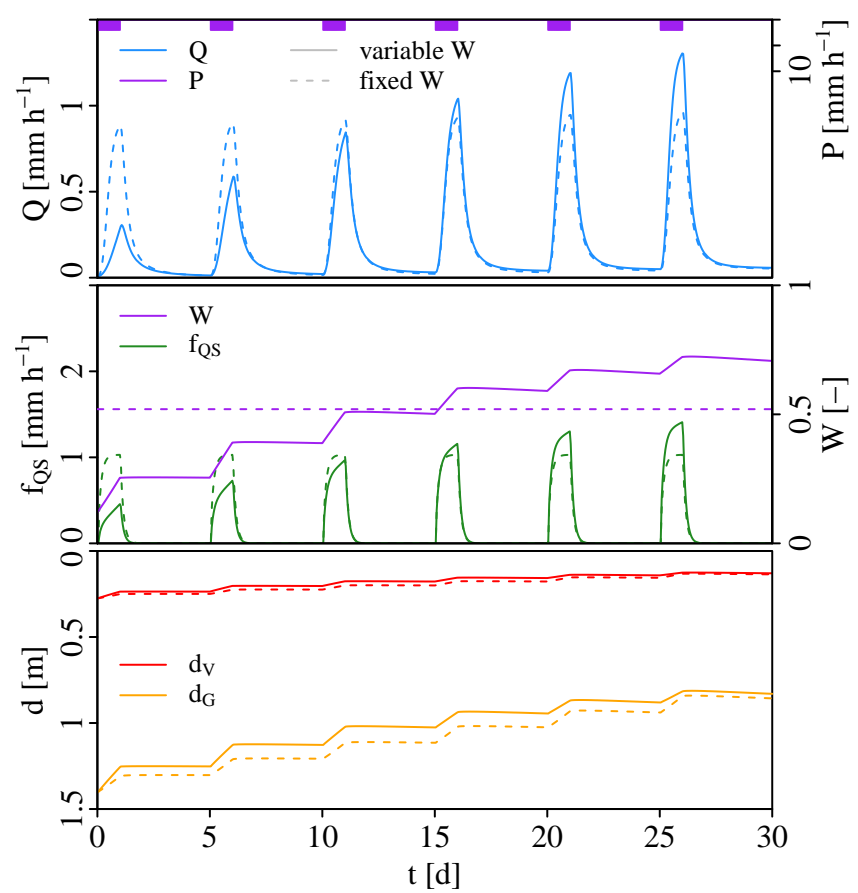

Figure 5. The isolated effect of including a wetness-dependent divider between slow and quick flow routes. Results of a numerical experiment with (solid) and without (dashed) a variable divider ( $W$; the wetness index). A change in $W$ does not only affect quickflow ( $\left.f_{\mathrm{QS}}\right)$, but propagates through the model and alters nearly all model variables: storage deficit $\left(d_{\mathrm{V}}\right)$, groundwater depth $\left(d_{\mathrm{G}}\right)$ and discharge $(Q)$. We used parameter values obtained for the Hupsel Brook catchment (Brauer et al., 2014, i.e. $c \mathrm{~W}=365 \mathrm{~mm}$, $c_{\mathrm{V}}=0.2 \mathrm{~h}, c_{\mathrm{G}}=5 \times 10^{6} \mathrm{~mm} \mathrm{~h}, c_{\mathrm{Q}}=3.3 \mathrm{~h}, c_{\mathrm{D}}=1500 \mathrm{~mm}, a_{\mathrm{S}}=$ 0.01 and the local $Q-h$ relation and soil parameters). See Table 1 for a list of all variable abbreviations.

\subsection{Precipitation and wetness index}

Precipitation $(P)$ is divided between the three reservoirs: a fixed fraction $a_{\mathrm{S}}$ falls directly onto the surface water $\left(P_{\mathrm{S}}\right)$ and the remainder is divided between the vadose zone $\left(P_{\mathrm{V}}\right)$ and the quickflow reservoir $\left(P_{\mathrm{Q}}\right)$. The wetness index $(W)$ gives the fraction of the rainfall that is led to the quickflow reservoir and ranges from 0 (dry - all water is led to the soil reservoir) to 1 (wet - all water is led to the quickflow reservoir). The wetness index is a function of storage deficit $\left(d_{\mathrm{V}}\right.$, Sect. 5.4). This relation can be supplied by the user, but as default a cosine function has been implemented, which starts at 1 when the soil is completely saturated $\left(d_{\mathrm{V}}=0\right)$ and drops to zero when $d_{\mathrm{V}}$ is equal to the wetness parameter $c_{\mathrm{W}}[\mathrm{mm}]$, which has to be calibrated:

$W=\cos \left(\frac{\max \left(\min \left(d_{\mathrm{V}}, c_{\mathrm{W}}\right), 0\right) \cdot \pi}{c_{\mathrm{W}}}\right) \cdot \frac{1}{2}+\frac{1}{2}$.

A negative value of $d_{\mathrm{V}}$ can occur in rare cases of largescale ponding (Sect. 5.11). Note that in WALRUS, ponding and overland flow can only be caused by saturation excess; infiltration excess is not considered.

The effect of this variable division between quick and slow flow paths is investigated by running WALRUS twice for an artificial example: with and without the variable $W$. Six rainfall events with a duration of one day and an intensity of $2 \mathrm{~mm} \mathrm{~h}^{-1}$, separated by four dry days yield the same quickflow $f_{\mathrm{QS}}$ and discharge $Q$ response when the divider is not dependent on soil moisture storage, but $f_{\mathrm{QS}}$ and $Q$ increase in the case of a wetness-dependent divider (Fig. 5). The storage deficit $d_{\mathrm{V}}$ decreases quickly during rainfall events and increases slowly in dry intervals. The variable wetness index $W$ follows $d_{\mathrm{V}}$ without delay and the groundwater depth $d_{\mathrm{G}}$ responds with a delay caused by the unsaturated zone (represented by its relaxation time parameter $c_{\mathrm{V}}$, see Sect. 5.6). With a variable $W$, the groundwater level rises quickly at first, but more slowly at the end, because less water is led to the soil reservoir when it is already wet. This numerical experiment shows that the variable wetness index ensures that WALRUS can simulate feedbacks between groundwater, vadose zone and quickflow and that variables at the soil surface do not only influence variables in the ground (as in most models), but also the other way around.

\subsection{Evapotranspiration}

Evapotranspiration (ET) takes place from the surface water reservoir $\left(\mathrm{ET}_{\mathrm{S}}\right)$ and the vadose zone $\left(\mathrm{ET}_{\mathrm{V}}\right)$. The actual evapotranspiration from the vadose zone depends on the potential evapotranspiration rate and the storage deficit (Fig. 6). The relation between the evapotranspiration reduction factor $\beta$ and the storage deficit can be supplied by the user. As a default, a two-parameter function has been implemented:

$\beta=\frac{\mathrm{ET}_{\mathrm{act}}}{\mathrm{ET}_{\mathrm{pot}}}=\frac{1-\exp \left[\zeta_{1}\left(d_{\mathrm{V}}-\zeta_{2}\right)\right]}{1+\exp \left[\zeta_{1}\left(d_{\mathrm{V}}-\zeta_{2}\right)\right]} \cdot \frac{1}{2}+\frac{1}{2}$.

The evapotranspiration reduction factor approaches one (no reduction) when the soil is saturated and decreases with storage deficit: first slowly, then more quickly and then more slowly again (although this end of the curve is never reached in practice). Equation (2) has two parameters: $\zeta_{1}$ determines the curvature and $\zeta_{2}$ determines at which value of $d \mathrm{~V}$ the reduction factor is 0.5 (the inflection point). Note that Eq. (2) does not account for the effects of waterlogging on transpiration, although the net effect on ET is likely limited because of the compensating effect of soil evaporation. In addition, under extremely dry conditions Eq. (2) will overestimate the soil moisture stress, but such conditions approach the limits of the range for which the assumptions behind WALRUS are valid.

Data from the two catchments (Sect. 3) are used to estimate $\zeta_{1}$ and $\zeta_{2}$ (Fig. 6). The scatter in the observed evapotranspiration data is very large, but when data points are collected in $25 \mathrm{~mm}$ wide sliding bins and averaged, a decrease in $\beta$ with $d_{\mathrm{V}}$ can be observed (orange-red line). In the 


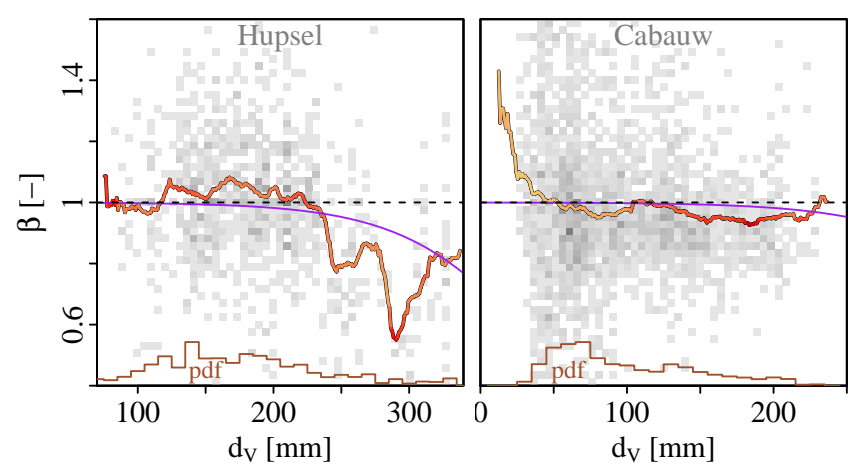

Figure 6. Determining the evapotranspiration reduction function. Soil moisture data are from the meteorological station in the Hupsel Brook catchment and the mean of four sites in the Cabauw polder. The orange-red lines connect the bin means, with the colour ranging from low (orange) to high (red) inverse variance. The purple lines, with coefficients $\zeta_{1}=0.02$ and $\zeta_{2}=400$, are implemented as default in WALRUS. The brown histograms are the probability density functions of storage deficit.

Cabauw polder, the storage deficit is never large and therefore hardly any evapotranspiration reduction occurs. In the Hupsel Brook catchment, reduction is around $10 \%$ when $d \mathrm{~V}$ exceeds $300 \mathrm{~mm}$, which corresponds to a rare groundwater depth of about $2 \mathrm{~m}$ (about $14 \%$ of the data in Fig. 6 was obtained during the extremely dry summer of 1976).

The open-water evaporation is assumed to be equal to the

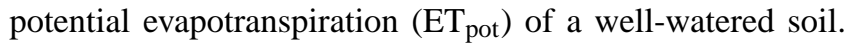
A Penman approximation would be more appropriate, but for most catchments only one estimate of evapotranspiration is available. In addition, the area fraction of open water and consequently the error is small. No evapotranspiration from the surface water occurs when the surface water reservoir is empty. Because the groundwater and surface water reservoirs together cover the entire catchment area, no evapotranspiration occurs from the quickflow reservoir. The effect of vegetation diversity on potential evapotranspiration can be accounted for by preprocessing.

\subsection{Storage deficit}

The dryness of the vadose zone is expressed by the storage deficit $\left(d_{\mathrm{V}}\right)$, representing the volume of empty soil pores per unit area, or in other words, the depth of water necessary to reach saturation. The vertical profile of soil moisture is not simulated explicitly and, as WALRUS is a lumped model, neither is its horizontal variability. The storage deficit controls the precipitation division between groundwater and quickflow $(W)$, evapotranspiration reduction $(\beta)$ and the change in groundwater depth $\left(d_{\mathrm{G}}\right)$ and is itself the result of all fluxes into or out of the soil reservoir, both the vadose zone and the groundwater zone.
Table 2. Parameters of the Brooks-Corey equilibrium soil moisture profile. The first 11 rows are taken from Clapp and Hornberger (1978). The last two lines are obtained from combined soil moisture and groundwater observations in the two catchments (see also Fig. 7).

\begin{tabular}{llll}
\hline Soil type & $\begin{array}{l}b \\
(-)\end{array}$ & $\begin{array}{l}\psi_{\mathrm{ae}} \\
(\mathrm{mm})\end{array}$ & $\begin{array}{l}\theta_{\mathrm{s}} \\
(-)\end{array}$ \\
\hline Sand & 4.05 & 121 & 0.395 \\
Loamy sand & 4.38 & 90 & 0.410 \\
Sandy loam & 4.90 & 218 & 0.435 \\
Silt loam & 5.30 & 786 & 0.485 \\
Loam & 5.39 & 478 & 0.451 \\
Sandy clay loam & 7.12 & 299 & 0.420 \\
Silt clay loam & 7.75 & 356 & 0.477 \\
Clay loam & 8.52 & 630 & 0.476 \\
Sandy clay & 10.40 & 153 & 0.426 \\
Silty clay & 10.40 & 490 & 0.492 \\
Clay & 11.40 & 405 & 0.482 \\
Hupsel & 2.63 & 90 & 0.418 \\
Cabauw & 16.77 & 9 & 0.639 \\
\hline
\end{tabular}

In the field, time series of storage deficit $\left(d_{\mathrm{V}}\right)$ can be estimated from soil moisture $(\theta[-])$ profile data. For each depth the soil moisture content at saturation $\left(\theta_{\mathrm{S}}[-]\right)$ has to be determined, which can often be done by taking the highest measured soil moisture content at that depth. The difference between the profiles of $\theta$ and $\theta_{\mathrm{s}}$ gives the profile of the fraction of soil filled with air (and the remainder, $1-\theta_{\mathrm{s}}$, gives the soil particle fraction). The storage deficit is obtained by integrating this air profile over depth $d$ from the groundwater table $d_{\mathrm{G}}$ to the soil surface:

$d_{\mathrm{V}}=\int_{0}^{d_{\mathrm{G}}}\left(\theta_{\mathrm{s}}-\theta\right) \mathrm{d} d$.

\subsection{Equilibrium storage deficit}

For every groundwater depth $d_{\mathrm{G}}$, an equilibrium soil moisture profile exists where at all depths gravity is balanced by capillary forces, and no flow occurs. From this profile the equilibrium storage deficit $d_{\mathrm{V} \text {,eq }}$ can be derived in the same way as $d_{\mathrm{V}}$, namely by integrating the volume of empty soil pores over depth. The relation between $d_{\mathrm{V} \text {,eq }}$ and $d_{\mathrm{G}}$ can be estimated from combined observations of groundwater and soil moisture. By assuming that on average $d_{\mathrm{V} \text {,eq }}$ equals $d_{\mathrm{V}}$, the relation can be read from a $\left(d_{\mathrm{G}}, d_{\mathrm{V}}\right)$-plot and supplied to WALRUS.

Alternatively, one can assume a relation based on parameterisations of steady-state (i.e. no-flow) profiles reported by e.g. Brooks and Corey (1964) and Van Genuchten (1980). WALRUS uses the power law of Brooks and Corey as default because it requires only two parameters. The profile of soil moisture content $\theta[-]$ as a function of 

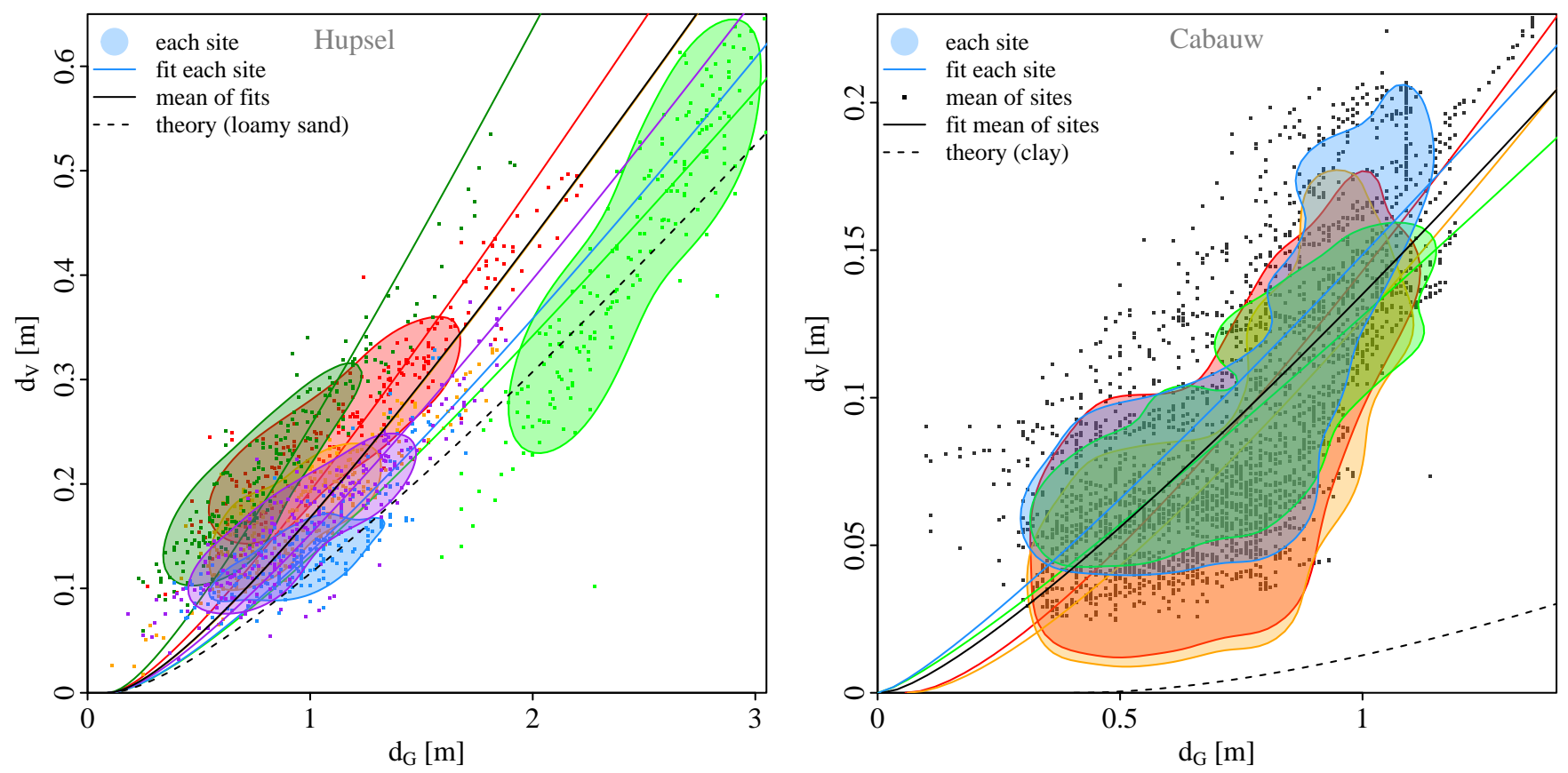

Figure 7. Relation between groundwater depth $d_{\mathrm{G}}$ and storage deficit $d_{\mathrm{V}}$. Coloured lines: data from six and four sites in the two catchments. Dashed black line: relation derived from the Brooks-Corey curve belonging to loamy sand (left) and clay (right). Coloured lines: relation with $b$ fitted on data. Solid black line: relation with the average $b$ of the stations. The clouds are represented by the contour lines encompassing $70 \%$ of the probability mass estimated using kernel densities (Wand and Jones, 1995).

height above the groundwater table $h[\mathrm{~mm}]$ according to Clapp and Hornberger (1978) is

$\theta=\theta_{\mathrm{s}}\left(\frac{h}{\psi_{\mathrm{ae}}}\right)^{-1 / b}$,

with $b$ the pore size distribution parameter [-] and $\psi_{\mathrm{ae}}$ the air entry pressure $[\mathrm{mm}]$. The air entry pressure raises the power law distribution above the groundwater table to allow for the capillary fringe (the saturated area above the groundwater table). The parameters $b, \psi_{\mathrm{ae}}$ and $\theta_{\mathrm{s}}$ differ per soil type and selected results from laboratory experiments by Clapp and Hornberger (1978) are given in Table 2 (see Cosby et al., 1984, for interpolations between soil types). When the part of the profile between the capillary fringe and the soil surface from Eq. (4) is substituted in Eq. (3), the relation between equilibrium storage deficit and groundwater depth becomes

$$
\begin{aligned}
d_{\mathrm{V}, \mathrm{eq}} & =\int_{\psi_{\mathrm{ae}}}^{d_{\mathrm{G}}}\left[\theta_{\mathrm{S}}-\theta_{\mathrm{S}}\left(\frac{h}{\psi_{\mathrm{ae}}}\right)^{-1 / b}\right] \mathrm{d} h \\
& =\theta_{\mathrm{S}}\left(d_{\mathrm{G}}-\frac{d_{\mathrm{G}}^{1-1 / b}}{\left(1-\frac{1}{b}\right) \psi_{\mathrm{ae}}^{-1 / b}}-\frac{\psi_{\mathrm{ae}}}{1-b}\right) .
\end{aligned}
$$

Heterogeneities, such as soil layering or disruption by plant roots, macrofauna and human activity, cause differences between laboratory and field observations. In Fig. 7
$d_{\mathrm{G}}$ is plotted as a function of $d_{\mathrm{V}}$ for several sites in the Hupsel Brook catchment and Cabauw polder area with corresponding theoretical curves. We computed the temporal maximum $\theta$ per depth (at the meteorological station in the Hupsel Brook catchment and the average of four profiles in the Cabauw polder) and averaged over the entire measured depth $(205 \mathrm{~cm}$ in the Hupsel Brook catchment and $72 \mathrm{~cm}$ in the Cabauw polder) to obtain a single value of $\theta_{\mathrm{s}}$. For the Hupsel Brook catchment, we fitted $b$ while retaining $\psi_{\mathrm{ae}}$, but for the Cabauw polder it was necessary to fit both $b$ and $\psi_{\mathrm{ae}}$ to obtain curves which describe the data points relatively well. The values obtained with these fits are listed in Table 2 . Note that the data are actual storage deficits, which may not be in equilibrium with the groundwater depth measured at the same time. In addition, sites differ considerably and will deviate from the catchment average.

\subsection{Percolation and capillary rise}

In practice, the soil moisture profile and storage deficit are never perfectly in equilibrium with the groundwater depth. Addition (e.g. through precipitation) and removal (e.g. by drainage or evapotranspiration) of water cause an imbalance between gravity and capillary forces, leading to downward (percolation) or upward (capillary rise) flow towards a new equilibrium situation. Because the flow decreases with proximity to the equilibrium, this equilibrium will only be reached asymptotically. 


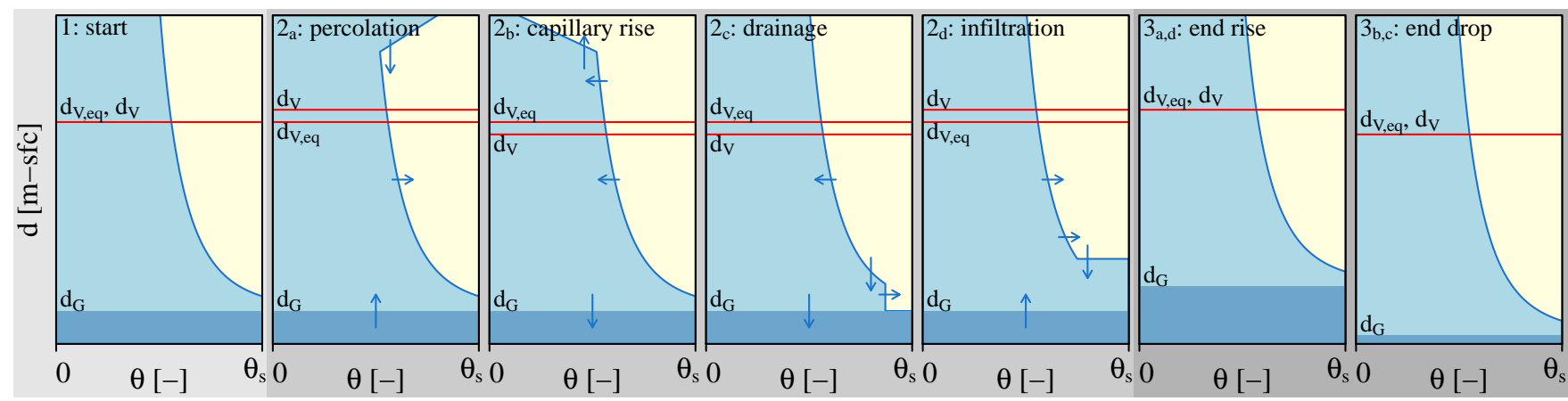

Figure 8. Illustration of the four scenarios for change in groundwater levels: (a) percolation after rainfall, (b) capillary rise after evapotranspiration, (c) percolation after drainage and (d) capillary rise after infiltration. WALRUS only simulates the solid lines of $d_{\mathrm{G}}, d_{\mathrm{V}}$ and $d_{\mathrm{V} \text {,eq }}$ rather than the profiles of relative saturation (dashed). The areas right of the curves (the integral of $\left(\theta_{\mathrm{S}}-\theta\right)$ over $d$ ) is equal to the values of $d_{\mathrm{V}}$.

The soil moisture profile is not simulated explicitly in WALRUS, but the temporal dynamics of $d_{\mathrm{V}}$ and $d_{\mathrm{G}}$ caused by the interactions between groundwater and vadose zone are taken into account. The groundwater depth responds to changes in storage deficit. The change in groundwater depth is parameterised as a function of the difference between the actual storage deficit (computed from the water budget in the soil reservoir) and the equilibrium storage deficit corresponding to the current groundwater level:

$\frac{\mathrm{d} d_{\mathrm{G}}}{\mathrm{d} t}=\frac{d_{\mathrm{V}}-d_{\mathrm{V}, \mathrm{eq}}}{c_{\mathrm{V}}}$,

with $c_{\mathrm{V}}$ the vadose zone relaxation time constant, which determines how quickly the system advances towards a new equilibrium.

Four situations may occur (illustrated in Fig. 8). (1) Water is added to the vadose zone through precipitation. The actual storage deficit is smaller than the equilibrium for the current groundwater depth. Water will flow downward and the groundwater level will rise gradually to the depth corresponding to the actual storage deficit. (2) Water is removed from the vadose zone through evapotranspiration. The actual storage deficit exceeds the equilibrium for the current groundwater depth. Water will flow upward to replenish the shortage in the top soil and the groundwater level will drop gradually. (3) Water is removed from the soil reservoir though drainage, downward seepage or groundwater extraction. Air is sucked into the soil and the actual storage deficit increases. This happens instantaneously, because water is incompressible. Water will percolate to reach an equilibrium profile again and the groundwater level will drop gradually. (4) Water is added to the soil reservoir through infiltration from surface water or upward seepage. The storage deficit decreases directly and the groundwater table rises gradually.

\subsection{Groundwater}

Drainage depends on the difference in water level between the surface water and groundwater reservoirs (rather than on groundwater levels alone), allowing for feedbacks and infiltration of surface water into the soil. Drainage of groundwater towards the surface water reservoir or infiltration of surface water $f_{\mathrm{GS}}$ is computed as

$f_{\mathrm{GS}}=\frac{\left(c_{\mathrm{D}}-d_{\mathrm{G}}-h_{\mathrm{S}}\right) \cdot \max \left(\left(c_{\mathrm{D}}-d_{\mathrm{G}}\right), h_{\mathrm{S}}\right)}{c_{\mathrm{G}}} \cdot a_{\mathrm{G}}$,

with $d_{\mathrm{G}}$ the depth of the groundwater table below the soil surface, $c_{\mathrm{G}}$ a reservoir constant $[\mathrm{mm} \mathrm{h}]$ and $c_{\mathrm{D}}$ the average channel depth [mm] (see also Table 1 and Fig. 4). The parameter $c_{\mathrm{G}}$ represents the combined effect of all resistance and variability therein and depends on soil type (hydraulic conductivity) and drainage density. The first term of Eq. (7), $c_{\mathrm{D}}-d_{\mathrm{G}}-h_{\mathrm{S}}$, expresses the pressure difference driving the flow. The second term, $\max \left(\left(c_{\mathrm{D}}-d_{\mathrm{G}}\right), h_{\mathrm{S}}\right)$, expresses the contact surface (parameterised as a depth) through which the flow takes place. These terms can be compared to the pressure head difference and layer thickness commonly used in groundwater models. The contact surface term accounts for decreasing drainage efficiency when groundwater and surface water levels drop and headwaters run dry. With this term, the variable source area concept (Beven and Kirkby, 1979) is implemented effectively and without additional parameters.

When groundwater drops below the surface water level, infiltration will be computed with the same relation, decreasing to zero when the surface water reservoir is empty (the second term $\max \left(\left(c_{\mathrm{D}}-d_{\mathrm{G}}\right), h_{\mathrm{S}}\right)$ becomes zero). The same parameter $c_{\mathrm{G}}$ is used for both groundwater drainage and surface water infiltration to limit the number of parameters, even though the resistance may be different in practice.

The groundwater-surface water feedback is illustrated by a numerical experiment. We ran the model for an artificial $3 \mathrm{~h}$ rainfall event with an intensity of $10 \mathrm{~mm} \mathrm{~h}^{-1}$ with and without using $h_{\mathrm{S}}$ in the drainage flux computation. Including $h_{\mathrm{S}}$ 
leads to a decrease in drainage $f_{\mathrm{GS}}$ and even infiltration (negative $f_{\mathrm{GS}}$ ) during the peak (Fig. 9, left panels). This causes an attenuation of the discharge peak and higher groundwater levels after the peak. This feedback is an important characteristic of WALRUS: in most parametric models, surface water levels are not modelled explicitly and this feedback cannot take place.

\subsection{Quickflow}

The quickflow reservoir simulates the combined effect of all water flowing through quickflow paths towards the surface water: overland, macropore and drainpipe flow. This reservoir can therefore be seen as a collection of ponds, small drainage trenches or gulleys, soil cracks, animal burrows and drainpipes. Quickflow $f_{\mathrm{QS}}$ depends linearly on the elevation of the water level in the quickflow reservoir $h_{\mathrm{Q}}$, with a time constant (reservoir constant) $c_{\mathrm{Q}}$ :

$f_{\mathrm{QS}}=\frac{h_{\mathrm{Q}}}{c_{\mathrm{Q}}} \cdot a_{\mathrm{G}}$

Water cannot flow from the surface water into the quickflow reservoir. Therefore, a sudden surface water level rise caused by an increase in surface water supply or weir elevation does not affect the quickflow reservoir directly.

The water level in the quickflow reservoir cannot be coupled to measurable variables directly - groundwater level measurements show the combined effect of the seasonal variation of the groundwater depth and the high-resolution dynamics of the quickflow reservoir. Even though quickflow is parameterised as a single linear reservoir, it is essential to include this reservoir to mimic the large and variable contribution of these flow routes (see Sect. 4.3).

\subsection{Surface water}

In WALRUS, surface water forms an integral part of the model structure. The surface water level $h_{\mathrm{S}}$ represents the water level in the average channel with respect to the channel bottom. The distance between channel bottom and soil surface $c_{\mathrm{D}}$ is calibrated or estimated from field observations. The stage-discharge relation $Q=$ func $\left(h_{\mathrm{S}}\right)$ specifies the relation between surface water level and discharge at the catchment outlet (in $\mathrm{mm} \mathrm{h}^{-1}$ ). It is provided by the user as a function, e.g. the relation belonging to the weir at the catchment outlet, or as a lookup table. A threshold level $h_{\mathrm{S}, \min }$ can be included in the stage-discharge relation to account for a weir or other water management structures. If applicable, a value or time series of $h_{\mathrm{S}, \min }$ should be provided. When the surface water level drops below the crest of a weir, discharge will be zero, but because there may still be drainage, infiltration and evaporation, it is important to include standing water. A default stage-discharge relation with the shape of a power law

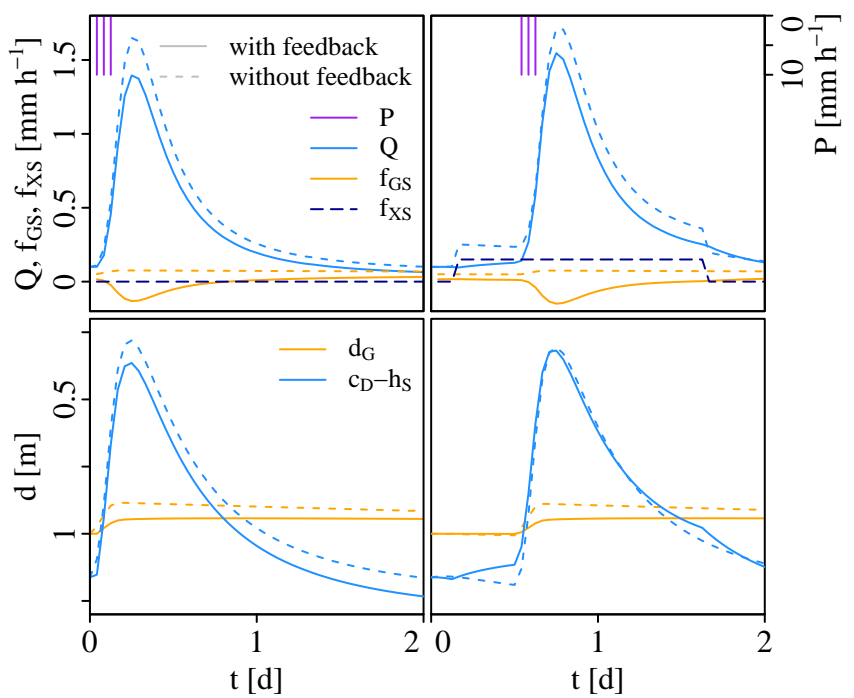

Figure 9. The isolated effect of taking into account the groundwater-surface water feedback process. Results of a numerical experiment with (solid) and without (dashed) using the surface water level $\left(h_{\mathrm{S}}\right)$ in the groundwater drainage flux $\left(f_{\mathrm{GS}}\right)$ computation. Right panels also include the effect of surface water supply $\left(f_{\mathrm{XS}}\right)$. For the dashed lines in the left panels, $h_{\mathrm{S}}$ was computed without $f_{\mathrm{XS}}$ and $f_{\mathrm{XS}}$ was added to the discharge $(Q)$ afterwards. The same parameter values as in Fig. 5 were used.

with a default exponent $x_{\mathrm{S}}$ of 1.5 has been implemented:

$Q=c_{\mathrm{S}}\left(\frac{h_{\mathrm{S}}-h_{\mathrm{S}, \min }}{c_{\mathrm{D}}-h_{\mathrm{S}, \min }}\right)^{x_{\mathrm{S}}}$

for $h_{\mathrm{S}} \leq c_{\mathrm{D}}$. The default exponent value 1.5 for $x_{\mathrm{S}}$ is inspired by equilibrium flow in open channels (Manning, 1889). The parameter $c_{\mathrm{S}}$ corresponds to the discharge at the catchment outlet (in $\mathrm{mm} \mathrm{h}^{-1}$ ) when the surface water level reaches the soil surface, comparable to the bankfull discharge. It can be calibrated or provided based on field observations.

\subsection{Seepage and surface water supply}

All fluxes across the catchment boundary, except for the discharge at the catchment outlet, are combined in the external groundwater flow term $f_{\mathrm{XG}}$ (downward or upward seepage and lateral groundwater inflow or outflow) and the external surface water flow term $f_{\mathrm{XS}}$ (supply or extraction). Positive values denote flow into the catchment. If applicable, time series of $f_{\mathrm{XG}}$ or $f_{\mathrm{XS}}$ should be provided by the user. Seepage and surface water supply are not parameterised, because they do not depend on processes within the catchment. In the case that no data are available, a groundwater or surface water management model could be used to obtain time series of seepage and surface water supply, which can be used as input for WALRUS. 
Because these fluxes are added to the soil reservoir or surface water reservoir, they influence other variables through the different feedbacks implemented in the model. Most parametric rainfall-runoff models do not contain a surface water reservoir and therefore surface water supply can only be added to discharge afterwards and the impact of surface water increase on groundwater level and the groundwater drainage flux is not considered.

To investigate the effect of WALRUS' set-up considering surface water supply, we modelled an artificial event with two model set-ups: (1) $f_{\mathrm{XS}}$ is added to the surface water reservoir and groundwater-surface water feedbacks are considered (as implemented in WALRUS) and (2) $f_{\mathrm{XS}}$ is added to $Q$ afterwards and $h_{\mathrm{S}}$ is not used in the groundwater drainage computation. Adding $f_{\mathrm{XS}}$ to the surface water reservoir causes a gradual increase in $h_{\mathrm{S}}$ and gradually rising $Q$ (Fig. 9, right panels). When $f_{\mathrm{XS}}$ is added to $Q$ afterwards, $h_{\mathrm{S}}$ is not affected by $f_{\mathrm{XS}}$ and only increases after rainfall, and $Q$ rises and falls instantly after changes in $f_{\mathrm{XS}}$. When a larger fraction of the catchment is covered by surface water $\left(a_{\mathrm{S}}\right)$, the increase in $h_{\mathrm{S}}$ and $Q$ becomes more gradual, because the supplied surface water volume is spread out over a larger surface. Including the groundwater-surface water feedback leads to an attenuated discharge peak, caused by a decrease in drainage as a result of a decreasing difference between $d_{\mathrm{G}}$ and $h_{\mathrm{S}}$. In dry periods, $f_{\mathrm{XS}}$ may cause $h_{\mathrm{S}}$ to rise above $d_{\mathrm{G}}$, leading to infiltration of surface water, which indicates that seepage and groundwater-surface water feedback should be implemented together.

\subsection{Large-scale ponding and flooding}

The quickflow reservoir simulates the effect of local ponding and overland flow, but large-scale ponding may also occur. When the storage deficit becomes zero (i.e. all soil pores are filled with water), the groundwater level will rise directly to the surface (as observed by Gillham, 1984; Brauer et al., 2011). Storage deficit and groundwater depth continue to drop (i.e. become more negative) together as there are no capillary forces any more and water level and pressure head coincide - negative $d_{\mathrm{V}}$ and $d_{\mathrm{G}}$ express ponding depths. Note that the levels rise less quickly above ground as the storativity becomes 1 .

Unfortunately, few quantitative, catchment-scale observations exist of different fluxes during floods. Because WALRUS has no spatial dimensions, the complex process of overland flow must be simplified. It is assumed that when the groundwater or surface water level rises above the soil surface, the groundwater drainage/surface water infiltration flux $f_{\mathrm{GS}}$ will include overland flow and is instantaneous, because overland flow is much faster than groundwater flow. When the surface water level exceeds the soil surface, discharge becomes less sensitive to changes in surface water level, represented by an abrupt change in the stage-discharge relation. However, as soon as the surface water level exceeds the soil surface, the excess water is led to the soil reservoir directly and therefore $h_{\mathrm{S}}$ hardly rises above the soil surface. Therefore, we keep the same stage-discharge relation when $h_{\mathrm{S}}>c_{\mathrm{D}}$ as a default. When the modelled groundwater table reaches the soil surface, an abrupt change in catchment discharge occurs. This is in contrast to the gradual activation of different flow paths when the catchment effective groundwater table is below surface (as represented by the wetness index).

We investigated the option of making the surface water area fraction $a_{\mathrm{S}}$ a function of $h_{\mathrm{S}}$, representing gradual widening of brooks and inundation of areas close to the surface water network, and thereby smoothing the effect of flooding on discharge at the catchment outlet. Unfortunately, this approach made the model structure less intuitive and introduced more degrees of freedom to define the shape of this function. Because flooding of the surface water reservoir only occurs during extremely wet situations, we chose to keep the model structure simple and leave $a_{\mathrm{S}}$ fixed.

\subsection{Outlook: possible model extensions}

Some processes are not taken into account in the core model yet, but a user could easily add preprocessing and postprocessing steps to adapt WALRUS to catchment-specific situations. (1) The potential evapotranspiration estimated at a meteorological station may not be representative for the collection of vegetation types in the catchment. Therefore, one could use land cover distributions and crop factors to determine the catchment average potential evapotranspiration. (2) Currently, WALRUS is set up to receive liquid precipitation, but preprocessing steps to account for snow and/or interception can be added. For example, the delay in precipitation input caused by snow accumulation and melt can be simulated with methods based on the land surface energy balance (Kustas et al., 1994) or a degree-day method (Seibert, 1997). (3) Interception can be parameterised with a threshold. Only the rainfall which exceeds the threshold is used as input for the model. The intercepted water evaporates directly and is not subtracted from $\mathrm{ET}_{\text {pot }}$ (Teuling and Troch, 2005). (4) Paved surfaces have a low infiltration capacity, which limits groundwater recharge. This can be parameterised by decreasing the groundwater reservoir area $a_{\mathrm{G}}$, introducing a paved surface area and leading the fraction of the rainfall belonging to this area directly to the surface water. (5) For large catchments, the discharge pulse from the model can be delayed and attenuated in the channels. It is possible to add a routing function to account for the delay and attenuation.

Another possibility is to couple WALRUS to other models. The outflow $Q$ of one catchment can be used as surface water supply $f_{\mathrm{XS}}$ for another WALRUS unit downstream. With this technique, one could make a chain of WALRUS units to model subcatchments (with possibly different catchment characteristics and therefore parameter values) separately. 
Groundwater flow from one unit to the next can be computed from groundwater levels in adjacent cells and Eq. (7). This groundwater flow is added to or subtracted from the seepage flux $f_{\mathrm{XG}}$ for both units. Regional groundwater flow from a distributed groundwater model can be added to or subtracted from the soil reservoir through the seepage flux $f_{\mathrm{XG}}$. This can be specified with a time series or an external groundwater level. The outflow of the model can be used as input for a hydraulic model. Discharge from an upstream catchment as computed from a hydraulic model can also be used as input $f_{\mathrm{XS}}$.

\section{Model implementation}

In this section we describe some key parts of the model implementation, which affect the model application and performance.

\subsection{Code set-up}

The model code is written in $\mathrm{R}$, but can be easily translated into any vector-oriented interpreted language. The code consists of several scripts. Two functions form the core of the model code: WALRUS_loop and WALRUS_step (provided as Supplement). In WALRUS_loop the initial conditions are set, a for-loop over each time step is run and output data are organised. For every time step, the function WALRUS_step is called, which contains the actual model computations. Some additional scripts (not included in the Supplement, but available upon request) provide help by preprocessing forcing data, setting default parameters, and postprocessing of the model output: figures, water balance computations and analysis of residuals. Another script provides a template in which functions are called for preprocessing, calibrating, running the model and postprocessing.

\subsection{Initial conditions}

The model can (as default) compute initial conditions for all states automatically, based on a stationary situation (thereby avoiding long burn-in periods). The quickflow reservoir is initially empty. The initial surface water level is derived from the first discharge observation and the stage-discharge relation. The initial groundwater depth is computed with the assumption that initial groundwater drainage $\left(f_{\mathrm{GS}}\right)$ is equal to the initial discharge. It is also possible to supply the fraction of the initial discharge originating from drainage $G_{\text {frac }}$ and the model will solve

$$
Q_{0} \cdot G_{\text {frac }}=\frac{\left(c_{\mathrm{D}}-d_{\mathrm{G}, 0}-h_{\mathrm{S}, 0}\right) \cdot\left(c_{\mathrm{D}}-d_{\mathrm{G}, 0}\right)}{c_{\mathrm{G}}}
$$

for $d_{\mathrm{G}, 0}$ with the quadratic formula and then use the remainder of the discharge to compute the initial quickflow reservoir level:

$h_{\mathrm{Q}, 0}=Q_{0} \cdot\left(1-G_{\mathrm{frac}}\right) \cdot c_{\mathrm{Q}}$.
Alternatively, the initial groundwater depth can be supplied (or calibrated) by the user and $h_{\mathrm{Q}, 0}$ is computed such that $Q_{0}=f_{\mathrm{GS}, 0}+f_{\mathrm{QS}, 0}$ again. The initial storage deficit is assumed to be the equilibrium value belonging to the initial groundwater depth.

A user can choose to use a warming-up period in case the uncertainty around the initial conditions is large. It is implemented in the code, but by default, the warming-up period is set to zero.

\subsection{Parameters}

WALRUS has four parameters which require calibration: $c_{\mathrm{W}}$, $c_{\mathrm{V}}, c_{\mathrm{G}}$ and $c_{\mathrm{Q}}$. These parameters have a physical meaning and can be explained qualitatively with catchment characteristics. The channel depth $c_{\mathrm{D}}$ and surface water area fraction $a_{\mathrm{S}}$ can be estimated from field observations. When the default stage-discharge relation is used, the bankfull discharge $c_{\mathrm{S}}$ and (if applicable) the weir elevation $h_{\mathrm{S} \text {, min }}$ need to be supplied (or calibrated) as well. Parameters are catchmentspecific, but time-independent, to allow a calibrated model to be run for both long periods and events. We did not implement a specific calibration routine in the model, but used the HydroPSO package, which is a particle swarm optimisation technique (Zambrano-Bigarini and Rojas, 2013). The user can define the (multi-)objective function.

\subsection{Forcing}

Forcing data can be supplied as a time series or as a function (e.g. a sine function for $\mathrm{ET}_{\text {pot }}$ or a Poisson rainfall generator). Observation times do not need to be equidistant, which is especially useful for tipping-bucket rain gauges. Forcing time series are converted to functions (e.g. cumulative $P$ as function of time), which allows other time steps than used for the original forcing.

\subsection{If-statements}

If-statements associated with thresholds cause nonlinearities in a model and their abrupt changes hamper calibration, in particular when using gradient-based methods. It is therefore important to know that there are four causes for abrupt changes in the model: (1) the stage-discharge relation (supplied by a user) may show abrupt changes at the elevation of the crest of the weir or at the soil surface; (2) no evaporation occurs from empty channel beds; (3) if the storage deficit becomes negative or exceeds the groundwater depth, the groundwater depth becomes equal to the storage deficit; (4) if either groundwater or surface water level exceeds the soil surface, overland flow is instantaneous.

\subsection{Integration scheme}

The model is implemented as an explicit scheme, because nonlinearities caused by feedbacks and if-statements do not 


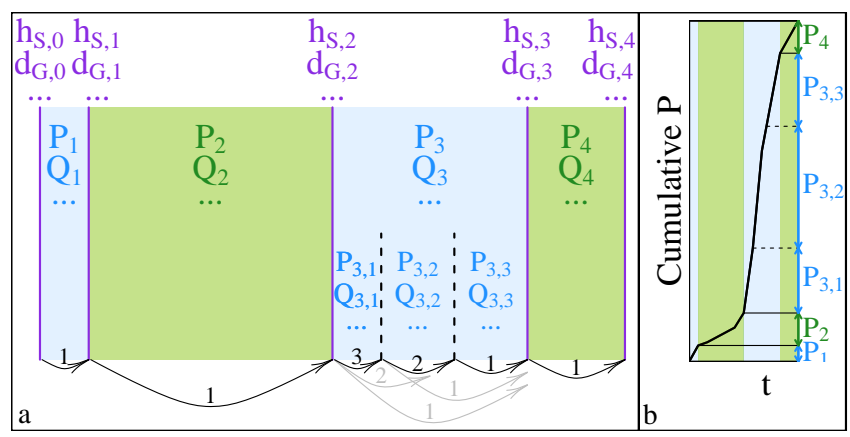

Figure 10. Illustration of the variable time step procedure. (a) The non-equidistant output time steps (purple) are used as first attempts for computations of fluxes (blue/green) and states (purple), but during time step number 3 , the precipitation sum is too large (panel b) and the step is divided into substeps: it is halved and then halved again until the criterion was reached. Note that even though the size of output time step 2 is larger, it is not divided into substeps, because all criteria are met.

allow for the use of an implicit scheme. The states at the end of the previous time step are used to compute the fluxes during the current time step, which are then used to compute the states at the end of the current time step (Fig. 10). The output data file lists the sums of the fluxes during and the states at the end of each time step.

\subsection{Time step}

The user can specify at which moments output should be generated, for example with a fixed interval (i.e. each hour or day), with increased frequency during certain events or after each millimetre of rainfall. The output time steps can be both larger and smaller than those of the forcing.

An important feature of the model code is the flexible computation time step. The model first attempts to run a whole output time step at once, but the time step is decreased when (1) the rainfall sum, discharge sum or change in discharge, surface water level or groundwater depth during the time step exceeds a certain threshold, or when (2) the surface water level is negative at the end of the time step. The first criterion prevents numerical instability caused by the explicit integration scheme and a delayed the response to rainfall as a result of the explicit model code (it takes one step to update the surface water level and another for the discharge). The second criterion is necessary because the total surface water outflow, computed from water levels at the start of the time step and the time step size, can exceed the available water. Because this means that non-existing water flowed out, there is a physical reason to avoid this.

The procedure of decreasing time steps is illustrated in Fig. 10 (third step). First the original time step is halved and the model is run for this substep (of course with the forcing corresponding to this substep). When the criteria are still not met, the step size will be halved again and again until the

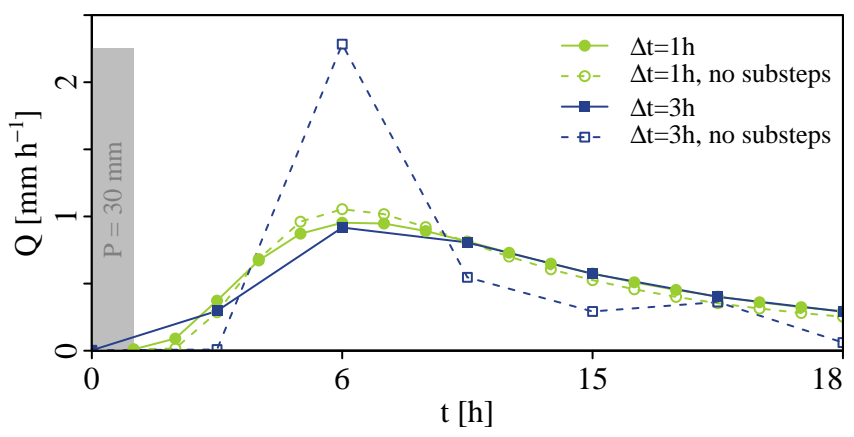

Figure 11. The effect of variable time steps on the model output. An artificial case with a rainfall event of $30 \mathrm{~mm}$ in the first hour and no evapotranspiration. The lines connect the discharge modelled at the end of a time step (instantaneous value), and do not represent the sum over the time step (which is given in the output file). The same parameter values as in Fig. 5 were used.

criteria are met. When one substep is completed, the fluxes are stored and the states at the end of the time step are used as initial values for the next substep. Then the model is run for the remainder of the original time step and, if necessary, the substep is halved until the criteria are met. This will continue until the end of the intended output time step is reached. The sum of the fluxes of the substeps and the states of the last substep are stored in the output file.

The effect of the variable time step is illustrated in Fig. 11, in which the output of the model run with a fixed time step and with variable time steps is shown. Note the erroneous time delay and magnitude of the discharge peak when no substeps are used, in particular for the 3-hourly time step.

\subsection{Water balance}

WALRUS is a mass conserving model, and therefore the model water budget, computed as

$$
\begin{array}{r}
\Sigma P-\Sigma \mathrm{ET}_{\mathrm{act}}-\Sigma Q+\Sigma f_{\mathrm{XG}}+\Sigma f_{\mathrm{XS}}= \\
-\Delta d_{\mathrm{V}} \cdot a_{\mathrm{G}}+\Delta h_{\mathrm{Q}} \cdot a_{\mathrm{G}}+\Delta h_{\mathrm{S}} \cdot a_{\mathrm{S}},
\end{array}
$$

always closes, although rounding errors may cause small deviations. The minus sign before $\Delta d_{\mathrm{V}}$ appears because $d_{\mathrm{V}}$ expresses a deficit and a decrease in storage deficit implies an increase in water in the reservoir. The groundwater level does not appear explicitly in the water balance, because it only plays a role as a pressure level driving groundwater drainage and surface water infiltration fluxes, while the storage deficit accounts for volume changes in the whole soil reservoir.

\section{Conclusions}

The Wageningen Lowland Runoff Simulator (WALRUS) is a new rainfall-runoff model, which is suitable for lowlands where shallow groundwater and surface water influence runoff generation. The model explicitly accounts for 
processes which are typically not included in parametric rainfall runoff models, but which are important in lowland areas:

1. Groundwater-unsaturated zone coupling - WALRUS contains one soil reservoir, which is divided effectively by the (dynamic) groundwater table into a groundwater zone and a vadose zone. The condition of this soil reservoir is described by two strongly dependent variables: the groundwater depth and the storage deficit (the effective thickness of empty pores). This implementation enables capillary rise when the top soil has dried through evapotranspiration.

2. Wetness-dependent flow routes - the storage deficit determines the division of rain water between the soil reservoir (slow routes: infiltration, percolation and groundwater flow) and a quickflow reservoir (quick routes: drainpipe, macropore and overland flow).

3. Groundwater-surface water feedbacks - surface water forms an explicit part of the model structure. Drainage depends on the difference between surface water level and groundwater level (rather than groundwater level alone), allowing for feedbacks and infiltration of surface water into the soil.

4. Seepage and surface water supply - groundwater seepage and surface water supply or extraction (pumping) are added to or subtracted from the soil or surface water reservoir. These external fluxes affect the whole system through the groundwater-surface water feedbacks and saturated-unsaturated zone coupling.

The open-source model code is implemented in $\mathrm{R}$ and the model is set up such that it can be used by both practitioners and researchers. For direct use by practitioners, defaults are implemented for relations between model variables and to compute initial conditions, leaving only four parameters which require calibration. For research purposes, the defaults can easily be changed. WALRUS is computationally efficient, which allows operational forecasting and uncertainty estimation by creating ensembles. An approach for flexible time steps increases numerical stability and makes model parameter values independent of time step size, which facilitates use of the model with the same parameter set for multi-year water balance studies as well as detailed analyses of individual flood peaks.

Numerical experiments shows that the implemented feedbacks have the desired effect on the system variables: (1) the wetness-dependent division between slow and quickflow routes results in more quickflow, less recharge and higher discharge peaks during wet periods; (2) the surface water level attenuates drainage during discharge peaks or when surface water is supplied upstream. An exhaustive test of WALRUS, with calibration, several validation studies, sensitivity analyses and uncertainty analyses in two catchments, the freely draining Hupsel Brook catchment and the controlled Cabauw polder, is presented in a companion paper (Brauer et al., 2014).

Compared to other rainfall-runoff models, WALRUS has some important advantages: it (1) is applicable to both freely draining and polder areas, (2) is computationally efficient, (3) has few parameters (only four to calibrate), (4) has a clear (qualitative) relation between model states and measurable variables, (5) has default options for initial conditions and parameterisations (which can easily be changed for research purposes), and (6) is open source and freeware (programmed in R). These advantages make WALRUS suitable for operational flood and drought forecasting, real-time control, input for hydraulic models, risk analyses, scenario analyses, infrastructure design and time series gap filling in lowland catchments. In that sense, WALRUS complements existing rainfall-runoff models, containing the core hydrological processes for lowlands, while maintaining a simple model structure. This makes WALRUS suitable for discharge simulations by researchers and practitioners alike.

\section{Code availability}

The complete model code can be obtained upon request (by emailing the first author). In addition, the code will be made available through the R CRAN website. WALRUS is licensed under the GPL v3 licence.

\section{The Supplement related to this article is available online at doi:10.5194/gmd-7-2313-2014-supplement.}

Acknowledgements. We thank Piet Warmerdam and Han Stricker for sharing their experience with the Wageningen model. We thank Roel Velner (Water Board Rivierenland), Gert van den Houten and Marian Koskamp (Water Board Rijn and IJssel), Frank Weerts (Water Board De Dommel), Jos Moorman (Water Board Aa and Maas), Jan Gooijer (Water Board Noorderzijlvest), Siebe Bosch and Ralph Pieters Kwiers (HydroConsult) and Klaas-Jan van Heeringen and Govert Verhoeven (Deltares) for their valuable insights from the end-user's perspective. We thank KNMI (especially Fred Bosveld) for evapotranspiration data in the Cabauw polder, the Water Board Rijn and IJssel for discharge and water quality data of the Hupsel Brook catchment and Rijkswaterstaat for soil moisture and groundwater data in the Hupsel Brook catchment. We thank Han Stricker, Jantine Bokhorst, Wilco Terink, Matthijs Boersema, Jacques Warmer, Wim Hovius and Marcel Brinkenberg for help with the field work in the Cabauw polder.

Edited by: J. Neal 


\section{References}

Abbott, M. B., Bathurst, J. C., Cunge, J. A., O'Connell, P. E., and Rasmussen, J.: An introduction to the European Hydrological System-Système Hydrologique Européen, "SHE", 1: History and philosophy of a physically-based, distributed modelling system, J. Hydrol., 87, 45-59, 1986.

Appels, W. M.: Water redistribution at the soil surface: ponding and surface runoff in flat areas, Ph.D. thesis, Wageningen University, 2013.

Appels, W. M., Bogaart, P. W., and van der Zee, S. E. A. T. M.: Influence of spatial variations of microtopography and infiltration on surface runoff and field scale hydrological connectivity, Adv. Water Resour., 34, 303-313, 2011.

Arnold, J. G., Srinivasan, R., Muttiah, R. S., and Williams, J. R.: Large area hydrologic modeling and assessment - Part 1: Model development, J. Am. Water Resour. As., 34, 73-89, 1998.

Beljaars, A. C. M. and Bosveld, F. C.: Cabauw data for the validation of land surface parameterization schemes, J. Climate, 10, 1172-1193, 1997.

Bergström, S. and Forsman, A.: Development of a conceptual deterministic rainfall-runoff model, Nord. Hydrol., 4, 147-170, 1973.

Beven, K.: Changing ideas in hydrology - the case of physicallybased models, J. Hydrol., 105, 157-172, 1989.

Beven, K.: Linking parameters across scales: subgrid parameterizations and scale dependent hydrological models, Hydrol. Process., 9, 507-525, 1995.

Beven, K. J. and Binley, A. M.: The future of distributed models: model calibration and uncertainty prediction, Hydrol. Process., 6, 297-298, 1992.

Beven, K. and Freer, J.: A dynamic topmodel, Hydrol. Process., 15, 1993-2011, 2001.

Beven, K. and Germann, P.: Macropores and water flow in soils, Water Resour. Res., 18, 1311-1325, 1982.

Beven, K. and Germann, P.: Macropores and water flow in soils revisited, Water Resour. Res., 49, 3071-3092, 2013.

Beven, K. J. and Kirkby, M. J.: A physically based, variable contributing area model of basin hydrology, Hydrol. Sci. J., 24, 4369, 1979.

Bogaart, P. W., Teuling, A. J., and Troch, P. A.: A state-dependent parameterization of saturated-unsaturated zone interaction, Water Resour. Res., 44, W11423, doi:10.1029/2007WR006487, 2008.

Bormann, H. and Elfert, S.: Application of WaSiM-ETH model to Northern German lowland catchments: model performance in relation to catchment characteristics and sensitivity to land use change, Adv. Geosci., 27, 1-10, doi:10.5194/adgeo-27-1-2010, 2010.

Brauer, C. C., Teuling, A. J., Overeem, A., van der Velde, Y., Hazenberg, P., Warmerdam, P. M. M., and Uijlenhoet, R.: Anatomy of extraordinary rainfall and flash flood in a Dutch lowland catchment, Hydrol. Earth Syst. Sci., 15, 1991-2005, doi:10.5194/hess15-1991-2011, 2011.

Brauer, C. C., Teuling, A. J., Torfs, P. J. J. F., and Uijlenhoet, R.: Investigating storage-discharge relations in a lowland catchment using hydrograph fitting, recession analysis, and soil moisture data, Water Resour. Res., 49, 4257-4264, 2013.

Brauer, C. C., Torfs, P. J. J. F., Teuling, A. J., and Uijlenhoet, R.: The Wageningen Lowland Runoff Simulator (WALRUS): application to the Hupsel Brook catchment and the Cabauw polder,
Hydrol. Earth Syst. Sci., 18, 4007-4028, doi:10.5194/hess-184007-2014, 2014.

Brooks, R. H. and Corey, A. T.: Hydraulic properties of porous media, Hydrology Paper 3, Colorado State University, Fort Collins, CO, 27 pp., 1964.

Brunner, G. W.: HEC-RAS River Analysis System. Hydraulic Reference Manual. Version 1.0., Tech. rep., DTIC Document, US Army Corps of Engineers, Davis, USA, 1995.

Burnash, R. J. C.: The NWS river forecast system - catchment modeling, in: Computer Models of Watershed Hydrology, edited by: Singh, V. P., Water Resour. Publ., Highlands Ranch, Colorado, USA, 311-366, 1995.

Canadell, J., Jackson, R. B., Ehleringer, J. B., Mooney, H. A., Sala, O. E., and Schulze, E. D.: Maximum rooting depth of vegetation types at the global scale, Oecologia, 108, 583-595, 1996.

Chen, X. and Hu, Q.: Groundwater influences on soil moisture and surface evaporation, J. Hydrol., 297, 285-300, 2004.

Clapp, R. B. and Hornberger, G. M.: Empirical equations for some hydraulic properties, Water Resour. Res., 14, 601-604, 1978.

Clark, M. P., Slater, A. G., Rupp, D. E., Woods, R. A., Vrugt, J. A., Gupta, H. V., Wagener, T., and Hay, L. E.: Framework for Understanding Structural Errors (FUSE): a modular framework to diagnose differences between hydrological models, Water Resour. Res., 44, W00B02, doi:10.1029/2007WR006735, 2008.

Cosby, B. J., Hornberger, G. M., Clapp, R. B., and Ginn, T. R.: A statistical exploration of the relationships of soil moisture characteristics to the physical properties of soils, Water Resour. Res., 20, 682-690, 1984.

Delsman, J. R., Oude Essink, G. H. P., Beven, K. J., and Stuyfzand, P. J.: Uncertainty estimation of end-member mixing using generalized likelihood uncertainty estimation (GLUE), applied in a lowland catchment, Water Resour. Res., 49, 4792 4806, 2013.

Deltares: SOBEK, 1D/2D modelling suite for integral water solutions: hydrodynamics, rainfall runoff and real-time control, Deltares, Delft, available at: www.deltares.nl (last access: 1 September 2014), 2013.

Dunne, T. and Black, R. D.: Partial area contributions to storm runoff in a small New England watershed, Water Resour. Res. 6, 1296-1311, 1970.

Edijatno, de Oliveira Nascimento, N., Yang, X., Makhlouf, Z., and Michel, C.: GR3J: a daily watershed model with three free parameters, Hydrol. Sci. J., 44, 263-277, 1999.

Efstratiadis, A. and Koutsoyiannis, D.: One decade of multiobjective calibration approaches in hydrological modelling: a review, Hydrol. Sci. J., 55, 58-78, 2010.

Fan, Y., Li, H., and Miguez-Macho, G.: Global patterns of groundwater table depth, Science, 339, 940-943, 2013.

Fenicia, F., Savenije, H. H. G., Matgen, P., and Pfister, L.: Is the groundwater reservoir linear? Learning from data in hydrological modelling, Hydrol. Earth Syst. Sci., 10, 139-150, doi:10.5194/hess-10-139-2006, 2006.

Fenicia, F., Kavetski, D., and Savenije, H. H. G.: Elements of a flexible approach for conceptual hydrological modeling: 1. Motivation and theoretical development, Water Resour. Res., 47, W11510, doi:10.1029/2010WR010174, 2011.

Gillham, R. W.: The capillary fringe and its effect on water-table response, J. Hydrol., 67, 307-324, 1984. 
Gupta, H. V., Sorooshian, S., and Yapo, P. O.: Toward improved calibration of hydrologic models: multiple and noncommensurable measures of information, Water Resour. Res., 34, 751-763, 1998.

Hall, F. R.: Base-flow recessions - a review, Water Resour. Res., 4, 973-983, 1968.

Hansen, A. L., Refsgaard, J. C., Christensen, B. S. B., and Jensen, K. H.: Importance of including small-scale tile drain discharge in the calibration of a coupled groundwater-surface water catchment model, Water Resour. Res., 49, 585-603, 2013.

Herrmann, A. and Duncker, D.: Runoff formation in a tile-drained agricultural basin of the Harz Mountain foreland, northern Germany, Soil Water Res., 3, 83-97, 2008.

Hopmans, J. and van Immerzeel, C.: Variation in evapotranspiration and capillary rise with changing soil profile characteristics, Agr. Water Manage., 13, 295-305, 1988.

Jakeman, A. J. and Hornberger, G. M.: How much complexity is warranted in a rainfall-runoff model?, Water Resour. Res., 29, 2637-2649, 1993.

Jarvis, N. J.: A simple empirical model of root water uptake, J. Hydrol., 107, 57-72, 1989.

Kirchner, J.: Getting the right answers for the right reasons: linking measurements, analyses, and models to advance the science of hydrology, Water Resour. Res., 42, W03S04, doi:10.1029/2005WR004362, 2006.

Kirchner, J. W.: Catchments as simple dynamical systems: catchment characterization, rainfall-runoff modeling, and doing hydrology backwards, Water Resour. Res., 45, W02429, doi:10.1029/2008WR006912, 2009.

Koch, S., Bauwe, A., and Lennartz, B.: Application of the SWAT Model for a tile-drained lowland catchment in north-eastern Germany on subbasin scale, Water Resour. Manag., 27, 791-805, 2013.

Koster, R. D., Suarez, M. J., Ducharne, A., Stieglitz, M., and Kumar, P.: A catchment-based approach to modeling land surface processes in a general circulation model: 1 . Model structure, J. Geophys. Res.-Atmos., 105, 24809-24822, 2000.

Krause, S. and Bronstert, A.: The impact of groundwater-surface water interactions on the water balance of a mesoscale lowland river catchment in northeastern Germany, Hydrol. Process., 21, 169-184, 2007.

Krause, S., Bronstert, A., and Zehe, E.: Groundwater-surface water interactions in a North German lowland floodplain - implications for the river discharge dynamics and riparian water balance, J. Hydrol., 347, 404-417, 2007.

Krzysztofowicz, R.: The case for probabilistic forecasting in hydrology, J. Hydrol., 249, 2-9, 2001.

Kustas, W. P., Rango, A., and Uijlenhoet, R.: A simple energy budget algorithm for the snowmelt runoff model, Water Resour. Res., 30, 1515-1527, 1994.

Lasserre, F., Razack, M., and Banton, O.: A GIS-linked model for the assessment of nitrate contamination in groundwater, J. Hydrol., 224, 81-90, 1999.

Liang, X., Lettenmaier, D. P., and Wood, E. F.: One-dimensional statistical dynamic representation of subgrid spatial variability of precipitation in the two-layer variable infiltration capacity model, J. Geophys. Res., 101, 21403-21421, 1996.

Liu, Y., Weerts, A. H., Clark, M., Hendricks Franssen, H.-J., Kumar, S., Moradkhani, H., Seo, D.-J., Schwanenberg, D., Smith, P., van Dijk, A. I. J. M., van Velzen, N., He, M., Lee, H., Noh, S. J.,
Rakovec, O., and Restrepo, P.: Advancing data assimilation in operational hydrologic forecasting: progresses, challenges, and emerging opportunities, Hydrol. Earth Syst. Sci., 16, 3863-3887, doi:10.5194/hess-16-3863-2012, 2012.

Makkink, G. F.: Testing the Penman formula by means of lysimeters, Int. J. Water. Eng., 11, 277-288, 1957.

Manning, R.: On the flow of water in open channels and pipes, Trans. Inst. Civ. Eng. Ireland, 20, 161-207, 1889.

McDonald, M. G. and Harbaugh, A. W.: A modular threedimensional finite-difference ground-water flow model, USGS Numbered Series 83-875, US Geological Survey, Denver, USA, 1984.

McDonnell, J. J.: Where does water go when it rains? Moving beyond the variable source area concept of rainfall-runoff response, Hydrol. Process., 17, 1869-1875, 2003.

McDonnell, J. J., Sivapalan, M., Vaché, K., Dunn, S., Grant, G., Haggerty, R., Hinz, C., Hooper, R., Kirchner, J., and Roderick, M. L.: Moving beyond heterogeneity and process complexity: a new vision for watershed hydrology, Water Resour. Res., 43, W07301, doi:10.1029/2006WR005467, 2007.

Moore, R. J.: The probability-distributed principle and runoff production at point and basin scales, Hydrolog. Sci. J., 30, 273-297, 1985.

Moore, R. J.: The PDM rainfall-runoff model, Hydrol. Earth Syst. Sci., 11, 483-499, doi:10.5194/hess-11-483-2007, 2007.

Mosley, M. P.: Streamflow generation in a forested watershed, New Zealand, Water Resour. Res., 15, 795-806, 1979.

Perrin, C., Michel, C., and Andréassian, V.: Does a large number of parameters enhance model performance? Comparative assessment of common catchment model structures on 429 catchments, J. Hydrol., 242, 275-301, 2001.

Perrin, C., Michel, C., and Andréassian, V.: Improvement of a parsimonious model for streamflow simulation, J. Hydrol., 279, 275289, 2003.

Prinsen, G. F. and Becker, B. P. J.: Application of Sobek hydraulic surface water models in the Netherlands hydrological modelling instrument, Irrig. Drain., 60, 35-41, 2011.

Querner, E. P.: Description of a regional groundwater flow model SIMGRO and some applications, Agr. Water Manage., 14, 209218, 1988.

Rakovec, O., Weerts, A. H., Hazenberg, P., Torfs, P. J. J. F., and Uijlenhoet, R.: State updating of a distributed hydrological model with Ensemble Kalman Filtering: effects of updating frequency and observation network density on forecast accuracy, Hydrol. Earth Syst. Sci., 16, 3435-3449, doi:10.5194/hess-163435-2012, 2012.

Refsgaard, J. C. and Storm, B.: MIKE SHE, in: Computer Models of Watershed Hydrology, edited by: Singh, V., Water Resources Publications, Colorado, USA, 809-846, 1995.

Rozemeijer, J. C., van der Velde, Y., van Geer, F. C., Bierkens, M. F. P., and Broers, H. P.: Direct measurements of the tile drain and groundwater flow route contributions to surface water contamination: from field-scale concentration patterns in groundwater to catchment-scale surface water quality, Environ. Pollut., 158, 3571-3579, 2010a.

Rozemeijer, J. C., van der Velde, Y., van Geer, F. C., de Rooij, G. H., Torfs, P. J. J. F., and Broers, H. P.: Improving load estimates for $\mathrm{NO}_{3}$ and $\mathrm{P}$ in surface waters by characterizing the concentra- 
tion response to rainfall events, Environ. Sci. Technol., 44, 6305$6312,2010 \mathrm{~b}$.

Schenk, H. J. and Jackson, R. B.: The global biogeography of roots, Ecol. Monogr., 72, 311-328, 2002.

Schulla, J. and Jasper, K.: Model Description WaSiM-ETH, Institute for Atmospheric and Climate Science, Swiss Federal Institute of Technology, Zürich, 2007.

Seibert, J.: Estimation of parameter uncertainty in the HBV model, Nord. Hydrol., 28, 247-262, 1997.

Seibert, J.: Multi-criteria calibration of a conceptual runoff model using a genetic algorithm, Hydrol. Earth Syst. Sci., 4, 215-224, doi:10.5194/hess-4-215-2000, 2000.

Seibert, J. and McDonnell, J. J.: On the dialog between experimentalist and modeler in catchment hydrology: use of soft data for multicriteria model calibration, Water Resour. Res., 38, 1241, doi:10.1029/2001WR000978, 2002.

Šimůnek, J., van Genuchten, M. T., and Šejna, M.: The HYDRUS1D software package for simulating the one-dimensional movement of water, heat, and multiple solutes in variably-saturated media, Tech. Rep. 3, KNMI, The Bilt, The Netherlands, 2008.

Sophocleous, M. and Perkins, S. P.: Methodology and application of combined watershed and ground-water models in Kansas, J. Hydrol., 236, 185-201, 2000.

Soulsby, C., Rodgers, P. J., Petry, J., Hannah, D. M., Malcolm, I. A., and Dunn, S. M.: Using tracers to upscale flow path understanding in mesoscale mountainous catchments: two examples from Scotland, J. Hydrol., 291, 174-196, 2004.

Soulsby, C., Neal, C., Laudon, H., Burns, D. A., Merot, P., Bonell, M., Dunn, S. M., and Tetzlaff, D.: Catchment data for process conceptualization: simply not enough?, Hydrol. Process., 22, 2057-2061, 2008.

Stenitzer, E., Diestel, H., Zenker, T., and Schwartengräber, R.: Assessment of capillary rise from shallow groundwater by the simulation model SIMWASER using either estimated pedotransfer functions or measured hydraulic parameters, Water Resour. Manag., 21, 1567-1584, 2007.

Stricker, J. N. M. and Brutsaert, W.: Actual evapotranspiration over a summer in the Hupsel Catchment, J. Hydrol., 39, 139-157, 1978.

Stricker, J. N. M. and Warmerdam, P. M. M.: Estimation of the water balance in the Hupselse Beek basin over a period of three years and a first effort to simulate the rainfall-runoff process for a complete year, in: Proceedings of the International symposium on hydrological research basins and their use in water resources planning, 21-23 September 1982, Bern, Switzerland, 379-388, 1982.

Sugawara, M., Ozaki, E., Watanabe, I., and Katsuyama, Y.: Tank Model and its Application to Bird Creek, Wollombi Brook, Bikin River, Kitsu River, Sanaga River and Nam Mune, vol. 11, National Research Center for Disaster Prevention, Tsukuba, Japan, 1974.

Te Brake, B., van der Ploeg, M. J., and de Rooij, G. H.: Water storage change estimation from in situ shrinkage measurements of clay soils, Hydrol. Earth Syst. Sci., 17, 1933-1949, doi:10.5194/hess-17-1933-2013, 2013.

Tetzlaff, D., Soulsby, C., Waldron, S., Malcolm, I. A., Bacon, P. J., Dunn, S. M., Lilly, A., and Youngson, A. F.: Conceptualization of runoff processes using a geographical information system and tracers in a nested mesoscale catchment, Hydrol. Process., 21, 1289-1307, 2007.

Teuling, A. J. and Troch, P. A.: Improved understanding of soil moisture variability dynamics, Geophys. Res. Lett., 32, L05404, doi:10.1029/2004GL021935, 2005.

Teuling, A. J., Uijlenhoet, R., Hupet, F., and Troch, P. A.: Impact of plant water uptake strategy on soil moisture and evapotranspiration dynamics during drydown, Geophys. Res. Lett., 33, L03401, doi:10.1029/2005GL025019, 2006.

Therrien, R., McLaren, R. G., Sudicky, E. A., and Panday, S. M.: HydroGeoSphere: A Three-Dimensional Numerical Model Describing Fully-Integrated Subsurface and Surface Flow and Solute Transport, Groundwater Simul. Group, Waterloo, Ont., Canada, 2006.

Thom, A. and Oliver, H.: On Penman's equation for estimating regional evaporation, Q. J. Roy. Meteor. Soc., 103, 345-357, 1977.

Tiemeyer, B., Moussa, R., Lennartz, B., and Voltz, M.: MHYDASDRAIN: a spatially distributed model for small, artificially drained lowland catchments, Ecol. Model., 209, 2-20, 2007.

Todini, E.: The ARNO rainfall-runoff model, J. Hydrol., 175, 339_ 382, 1996.

Tromp-van Meerveld, H. J. and McDonnell, J. J.: Threshold relations in subsurface stormflow: 2. The fill and spill hypothesis, Water Resour. Res., 42, W02411, doi:10.1029/2004WR003800, 2006.

Turunen, M., Warsta, L., Paasonen-Kivekäs, M., Nurminen, J., Myllys, M., Alakukku, L., Äijö, H., Puustinen, M., and Koivusalo, H.: Modeling water balance and effects of different subsurface drainage methods on water outflow components in a clayey agricultural field in boreal conditions, Agr. Water Manage., 121, 135-148, 2013.

Uhlenbrook, S., Seibert, J., Leibundgut, C., and Rodhe, A.: Prediction uncertainty of conceptual rainfall-runoff models caused by problems in identifying model parameters and structure, Hydrol. Sci. J., 44, 779-797, 1999.

Van Andel, S. J., Price, R., Lobbrecht, A., and van Kruiningen, F.: Modeling controlled water systems, J. Irrig. Drain. E.-ASCE, 136, 392-404, 2010.

Van Dam, J. C., Groenendijk, P., Hendriks, R. F. A., and Kroes, J. G.: Advances of modeling water flow in variably saturated soils with SWAP, Vadose Zone J., 7, 640-653, 2008.

Van den Eertwegh, G. A. P. H., Nieber, J. L., de Louw, P. G. B., van Hardeveld, H. A., and Bakkum, R.: Impacts of drainage activities for clay soils on hydrology and solute loads to surface water, Irrig. Drain., 55, 235-245, 2006.

Van der Ploeg, M. J., Appels, W. M., Cirkel, D. G., Oosterwoud, M. R., Witte, J.-P. M., and van der Zee, S. E. A. T. M.: Microtopography as a driving mechanism for ecohydrological processes in shallow groundwater systems, Vadose Zone J., 11, doi:10.2136/vzj2011.0098, 2012.

Van der Velde, Y., de Rooij, G. H., and Torfs, P. J. J. F.: Catchment-scale non-linear groundwater-surface water interactions in densely drained lowland catchments, Hydrol. Earth Syst Sci., 13, 1867-1885, doi:10.5194/hess-13-1867-2009, 2009.

Van der Velde, Y., de Rooij, G. H., Rozemeijer, J. C., van Geer, F. C., and Broers, H. P.: Nitrate response of a lowland catchment: on the relation between stream concentration and travel time distribution dynamics, Water Resour. Res., 46, W11534, doi:10.1029/2010WR009105, 2010a. 
Van der Velde, Y., Rozemeijer, J. C., de Rooij, G. H., van Geer, F. C., and Broers, H. P.: Field-scale measurements for separation of catchment discharge into flow route contributions, Vadose Zone J., 9, 25-35, 2010b.

Van der Velde, Y., Rozemeijer, J. C., de Rooij, G. H., van Geer, F. C., Torfs, P. J. J. F., and de Louw, P. G. B.: Improving catchment discharge predictions by inferring flow route contributions from a nested-scale monitoring and model setup, Hydrol. Earth Syst. Sci., 15, 913-930, doi:10.5194/hess-15-913-2011, 2011.

Van Genuchten: A closed-form equation for predicting the hydraulic conductivity of unsaturated soils, Soil Sci. Soc. Am. J., 44, 892-898, 1980.

Van Walsum, P. E. V. and Groenendijk, P.: Quasi steady-state simulation of the unsaturated zone in groundwater modeling of lowland regions, Vadose Zone J., 7, 769-781, 2008.

Van Walsum, P. E. V., and Veldhuizen, A. A.: Integration of models using shared state variables: implementation in the regional hydrologic modelling system SIMGRO, J. Hydrol., 409, 363-370, 2011.

Vrugt, J. A., Diks, C. G., Gupta, H. V., Bouten, W., and Verstraten, J. M.: Improved treatment of uncertainty in hydrologic modeling: combining the strengths of global optimization and data assimilation, Water Resour. Res., 41, W01017, doi:10.1029/2004WR003059, 2005.

Vrugt, J. A., ter Braak, C. J. F., Clark, M. P., Hyman, J. M., and Robinson, B. A.: Treatment of input uncertainty in hydrologic modeling: doing hydrology backward with Markov chain Monte Carlo simulation, Water Resour. Res., 44, W00B09, doi:10.1029/2007WR006720, 2008.
Wagener, T.: Evaluation of catchment models, Hydrol. Process., 17, 3375-3378, 2003.

Wagener, T. and Wheater, H. S.: Rainfall-Runoff Modelling in Gauged and Ungauged Catchments, Imperial College Press, London, UK, 2004.

Wagener, T., Boyle, D. P., Lees, M. J., Wheater, H. S., Gupta, H. V., and Sorooshian, S.: A framework for development and application of hydrological models, Hydrol. Earth Syst. Sci., 5, 13-26, doi:10.5194/hess-5-13-2001, 2001.

Wand, M. and Jones, M.: Kernel Smoothing, Chapman and Hall, London, 1995.

Weiler, M. and McDonnell, J.: Virtual experiments: a new approach for improving process conceptualization in hillslope hydrology, J. Hydrol., 285, 3-18, 2004.

Weir, A. H. and Barraclough, P. B.: The effect of drought on the root growth of winter wheat and on its water uptake from a deep loam, Soil Use Manage., 2, 91-96, 1986.

Zambrano-Bigarini, M. and Rojas, R.: A model-independent particle swarm optimisation software for model calibration, Environ. Modell. Softw., 43, 5-25, 2013.

Zencich, S. J., Froend, R. H., Turner, J. V., and Gailitis, V.: Influence of groundwater depth on the seasonal sources of water accessed by Banksia tree species on a shallow, sandy coastal aquifer, Oecologia, 131, 8-19, 2002.

Zeng, F., Song, C., Guo, H., Liu, B., Luo, W., Gui, D., Arndt, S., and Guo, D.: Responses of root growth of Alhagi sparsifolia Shap. (Fabaceae) to different simulated groundwater depths in the southern fringe of the Taklimakan Desert, China, J. Arid Land, 5, 220-232, 2013. 